\title{
An Evaluation of Waste Disposal by Shale Fracturing
}

H. O. Weeren

PORTIONS OF THIS REPORT ARE ILLEGIBLE。 It has been reproduced from the best available copy to permit tho broadost possiblo availability. 


\section{DISCLAIMER}

This report was prepared as an account of work sponsored by an agency of the United States Government. Neither the United States Government nor any agency Thereof, nor any of their employees, makes any warranty, express or implied, or assumes any legal liability or responsibility for the accuracy, completeness, or usefulness of any information, apparatus, product, or process disclosed, or represents that its use would not infringe privately owned rights. Reference herein to any specific commercial product, process, or service by trade name, trademark, manufacturer, or otherwise does not necessarily constitute or imply its endorsement, recommendation, or favoring by the United States Government or any agency thereof. The views and opinions of authors expressed herein do not necessarily state or reflect those of the United States Government or any agency thereof. 


\section{DISCLAIMER}

Portions of this document may be illegible in electronic image products. Images are produced from the best available original document. 
Printed in the United States of America. Available from

National Technical Information Service

U.S. Department of Commerce

5285 Port Royal Road, Springfield, Virginia 22161

Price: Printed Copy $\$ 5.50$; Microfiche $\$ 2.25$

This report was prepared as an account of work sponsored by the United States Government. Neither the United States nor the Energy Research and Development Administration, nor any of their employees, nor any of their contractors, subcontractors, or their employees, makes any warranty, express or implied, or assumes any legal liability or responsibility for the accuracy, completeness or usefulness of any information, apparatus, product or process disclosed, or represents that its use would not infringe privately owned rights. 
Contract No. W-7405-eng-26

OPERATIONS DIVISION

AN EVALUATION OF WASTE DISPOSAL BY SHALE FRACTURING

H. 0 . Weeren

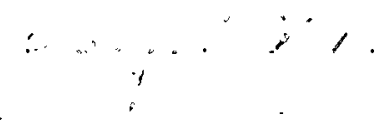

FEBRUARY: 1976

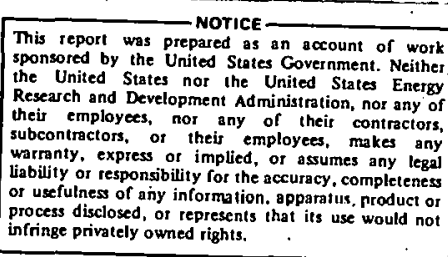

This report was prepared as an account of work
sponsored by the United Stotes Government. Neithes the United States nor the United States Energy their employees, nor any of their contrectors warranty express theis employees, makes any Wabilly or responsibility for the accuracy, completeness process disclosed, of represents that its use would no infringe privately owned rights.

NOTICE This dooumant oontoing information of o proliminary noturo and was prepared primarily for internal use at the Oak Aidge National Laboratory. It is subject to revision or correction and therefore does not represent a final report.

\author{
OAK RIDGE NATIONAL LABORATORY \\ Oak Ridge, Tennessee 37830 \\ operated by \\ UNION CARBIDE CORPORATION \\ for the \\ ENERGY RESEARCH AND DEVELOPMENT ADMINISTRATION
}




\section{THIS PAGE \\ WAS INTENTIONALLY \\ LEFT BLANK}


ABSTRACT $\ldots \ldots \ldots \ldots \ldots \ldots \ldots \ldots \ldots \ldots \ldots \ldots \ldots \ldots \ldots \ldots \ldots \ldots \ldots \ldots \ldots \ldots \ldots \ldots \ldots \ldots \ldots 1$

1.0 SUMMARY ...........

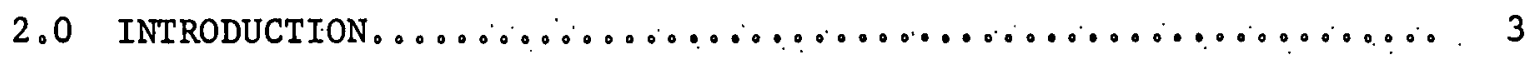

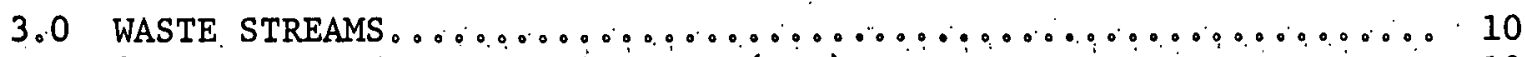

3.1 Intermedlate Level Waste (ILW) . . . . . . . . . . . . . . . . . 10

3.2 ILW Sludge

3.3 Organics ..................................... 13

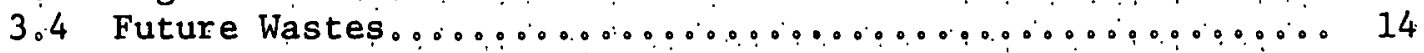

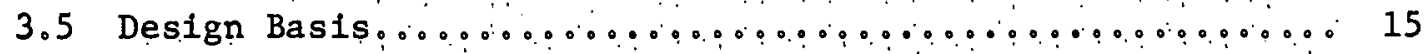

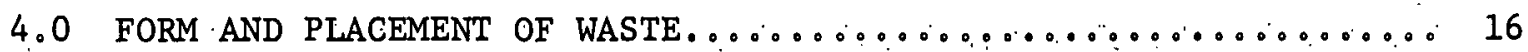

4.1 Properties of Waste Form.

4.2 Placement of Waste Form........................... 19

4.3 Description of Disposal Formation................... 21

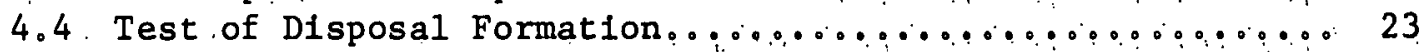

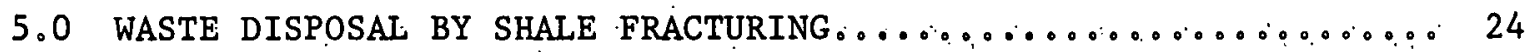

5.1 Process Description...................................... 24

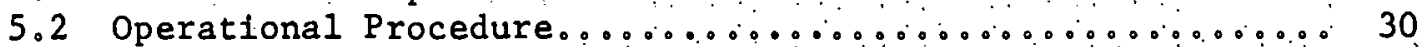

5.3 Injection Monitoring ... $\ldots \ldots \ldots \ldots \ldots \ldots \ldots \ldots \ldots \ldots \ldots \ldots \ldots \ldots \ldots \ldots$

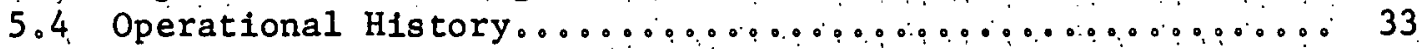

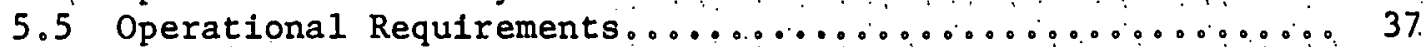

5.6 Research and Development Requirements................. 38

6.0. ESTIMATE OF COSTS

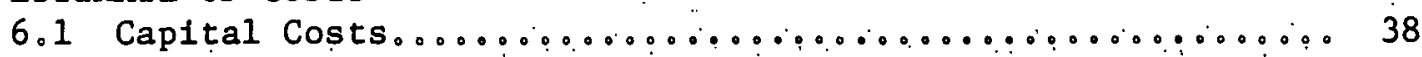

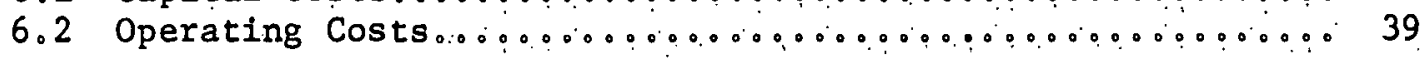

7.0 ENVIRONMENTAL AND SAFETY AGSEGSMENT

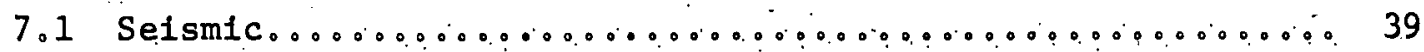

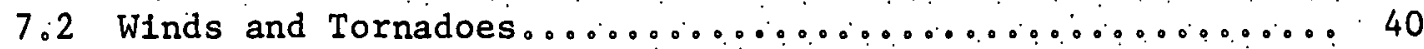

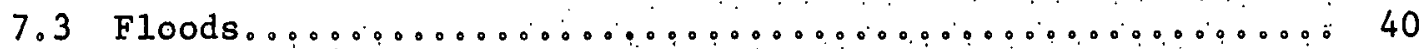

7.4 Fallure of Services.......

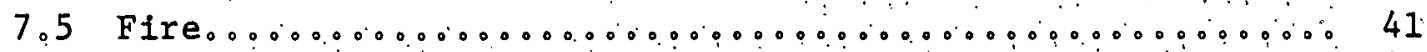

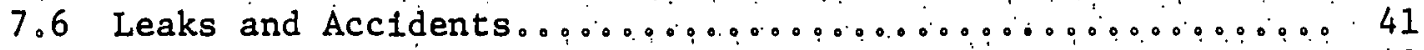

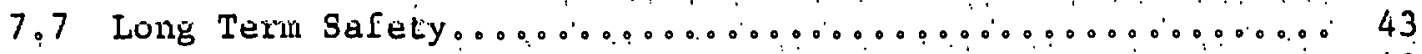

7.8 Analysis of Environmental Impact.................... 43

8.0 COMPARISON WITH ALTERNATIVE PROCESSES $\ldots \ldots \ldots \ldots \ldots \ldots \ldots \ldots \ldots, 43$

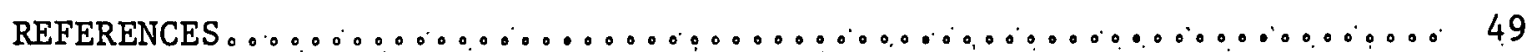




\section{THIS PAGE}

\section{WAS INTENTIONALLY LEFT BLANK}


Fig. 1. ORNL Fracturing Disposal Pilot Plant (ORNL Dwg. 63-3830)

Fig. 2. Schematic Flow Diagram - New ILW System (ORNL Dwg. 75-12355)

Fig. 3. Modifications to ORNL Liquid Waste System (ORNL Dwg. 73-3978R2)

Fig. 4. Leach Rates of ${ }^{137} \mathrm{Cs}$ from Grouts with Various Mix Additives (ORNL Dwg. 75-86R1)

Fig. 5. Core of Grout Sheet

(ORNL Photo No. 92724)

Fig. 6. Geologic Section Through Injection Well (ORNL Dwg. 65-833R3)

Fig. 7. East-West Section at Test Site (ORNL Dwg. 74-5299)

Fig. 8. Flow Diagram of New Shale Fracturing Facility (ORNL Dwg. 73-3976)

Fig. 9. Sketch of Wells for Fracturing Experiment (ORNL Dwg. 63-5234R2)

Fig. 10. Weight Ratio Injection ILW-10

(ORNL Dwg. 73-12718)

Fig. 11. Surface Uplift at Fracturing Site (ORNL Dwg. 73-3582R1) 
LIST OF TABLES

TABLE

PAGE

1 Cost Comparison for Waste Fixation Processes

2 Generated Volumes of ILW 10

3 Ionic Analyses of Four ILW Solutions 11

4 Nominal Chemical Composition of Four Waste Solutions 11

$5 \quad$ Radiochemical Analyses of Waste Solutions $\quad 12$

6 Properties of Sludge $\quad 13$

7 Waste Stream Composition - Design Basis 15

- 8 Composition of Dry Solids Mix 16

9 Injection Parameters for Routine Disposal of Waste Solution 35

10 Costs for 1972 Injection Series 38

11 Estimated Capital Cost of Shale Fracturing Facility 39 
AN EVALUATION OF - WASTE DISPOSAL BY SHALE - FRACTURING

H. O. Weeren

ABSTRACT

The shale fracturing process is evaluated as a means for permanent disposal of radioactive inter-. mediate level liquid waste generated at the Oak Ridge National Laboratory. The estimated capital operating and development costs of a proposed disposal facility are compared with equivalent estimated costs for alternative methods of waste fixation.

\subsection{SUMMARY}

Normal operations at the Oak RIdge National Laboratory generate up to two million gallons per year of Ințermediate level waste solution having an average concentration of a few hundreths of a curie per gallon. This solution is routinely neutrallzed with $\mathrm{NaOH}$ which precipitates those constltuents of the waste solution that are insoluble in alkaline solution. These solids, which contain the bulk of the ${ }^{90} \mathrm{Sr}$ and the actinides that have been discharged to the waste system,..settle and accumulate in the waste storage tanks. The supernate is concentrated by evaporation and is periodically disposed of by shale fracturing (a process for the fixation of the waste in an impermeable bedded shale formation at a depth of approximately $900 \mathrm{ft}$ ). Approximately 80,000 gal of concentrated waste solution is disposed of annually; the current generation rate for sludge is about $10,000 \mathrm{gal} / \mathrm{yr}$. About $400,000 \mathrm{gal}$ of sludge has accumulated from the operations of previous years and is presently held in various waste storage tanks.

This report is an evaluation of the shale fracturing process as one of several possible alternative processes for the management or disposal of intermediate level waste (ILW) solution or sludge that is generated at oak Ridge National Laboratory. 'Processes other than shale fracturing are discussed and evaluated in another report ${ }^{1}$. This report is a summary of current experience at ORNL with the shale fracturing process, a description of a proposed new facility for the disposal of future Laboratory waste, and some estimates of capital and disposal cosțs. 
The shale fracturing process. is a waste disposal process currently in use at Oak Ridge National Laboratory for the permanent disposal of 1ocally generated intermediate level waste solutions. In this process the waste solution is mixed with a solids blend of cement and other additives; the resulting grout is injected into impermeable shale formation at a depth of 700 to $1000 \mathrm{ft}$ - well below the level at which ground water is encountered. The injected grout forms a thin, approximately horizontal, grout sheet several hundred feet across during the course of the injection. A few hours after completion of the injection the grout sets, thereby. permanently fixing the radioactive waste in the shale formation.

The essential feature of the shale fracturing process is the fixation of the radionuclides in a geologic formation that is isolated from contact with the surface environment. Several independent lines of evidence indicate that the formations into which the injections are made are quite isolated and have been so for millennia. Additional features of the process would provide continued containment of the radionuclides even if the isolation of the disposal formation should be lost. The leach rate of significant radionuclides from the set grout is quite low. Also, the small quantity of radionuclide's that might be leached from a grout sheet would be retained in the disposal zone by the high ion exchange capacity of this shale.

The existing shale fracturing facility has been used to inject 1.8 million gal of waste grout containing 550,000 $\mathrm{Ci}$ of radionuclides and has performed quite satisfactorily. The clean up of small waste spills has been found to be feasible, as has the direct maintenance of mechanical equipment: The obșerved process shortcomings include the improper location of some equipment, some difficulty'with maintaining a steady solids flow, and a marginally effective control of solids to liquid proportioning. These shortcomings are not.serious and could be alleviated or corrected in a new facility。

The overall environmental impact of a new shale fracturing facility is expected to be beneficial. The facility would remove large volumes of potentially hazardous radioactive wastes from the existing surface storage facilities and $f i x$ these wastes in impermeable shale formations, well removed from the biosphere. All major accident situations that were postulated are considered to be quite improbable and the analysis of each case has indicated the ultimate release of radionuclides to the environment would be small. 
A detalled study has been made of possible alternative processes that could be used for the safe storage or disposal of the ILW solution and ILW sludge that are generated or stored at $\mathrm{ORNL}^{1}{ }^{1}$ Three possible alternative processes were selected for estimates of capital and operating costs. In each of these alternative processes the final waste form is stored in a facility from which it can beretrieved; the ultimate disposal of the immobilized waste is not a part of these processes. A comparison of the estimated capital costs, the research and development costs, and the annual operating costs for the alternative processes and for the shale fracture process 1s: shown in Table: 1 。

\subsection{INTTRODUCTION}

This report is an evaluation of the shale fracturing process as one of several possible alternative processes for the management or disposal of intermediate level waste (ILW) solution or sludge that is generated at Oak Ridge National Laboratory. Processes other than shale fracturing are discussed and evaluated in another report ${ }^{1}$ This report is a summary of current experience at ORNL with the shale fracturing process, a description of a proposed new facility for the disposal of future Laboratory waste and some estimates of capital and disposal costs.

The shale fracturing process is a waste disposal process currently in use at Oak Ridge National Laboratory for the permanent disposal of locally generated intermediate level waste solutions. In this process the waste solution is mixed with a solids blend of cement and other additives; the resulting grout is injected into impermeable shale formation at a depth of 700 to $1000 \mathrm{ft}$ - well below the level at which ground water is encountered. The initial fracture in the shale is generated by the hydraulic pressure of a small volume of water: Waste grout is then injected into this initial fracture. The injection pressure of the grout is sufficiently high to propagate a thin horizontal crack in the shale. As the injection of the grout continues, this crack is filled by the grout and is extended further so that a thin, approximately horizontal, grout sheet several hundred feet across is formed during the course of the injection. A fiew hours after completion of the injection the grout sets, thereby permanently fixing the 
Table 1. Cost Comparison for Waste Fixation Processes

\begin{tabular}{|c|c|c|c|c|c|}
\hline v & $\begin{array}{l}\text { Shale } \\
\text { Cement }\end{array}$ & $\begin{array}{l}\text { Cesium } \\
\text { Sṭrip. }\end{array}$ & $\begin{array}{c}\text { Cesium Strip } \\
\text { with } \\
\text { Shale Fracture }\end{array}$ & Glass : & $\begin{array}{l}\text { Shale } \\
\text { Fracture }\end{array}$ \\
\hline Estimated Capital Cost (1975) $\$ 10^{6}$ & 14.9 & 15.0 & 17.0 & $21: 8$ & 2.6 \\
\hline Annual Operating Cost,$\$ 10^{6}$ & 0.6 & 1.1 & 1.1 & $\ldots .5^{\circ}$ & 0.1 \\
\hline Annual Shipping Cost, $\$ 10^{6}$ & 1.6 & 1.0 & 1.0 & 1.0 & none \\
\hline Research and Development Cost $; \$ 10^{6}$ & 1.2 & 2.1 & 2.1 & 3.0 & 0.7 \\
\hline
\end{tabular}


radioactive wastes in the shale formation. Subsequent injections form sheets parallel to the first and a few feet above it. An isometric view of the system is shown in Fig. 1 。

At the Oak Ridge National Laboratory, intermediate level waste solution (defined as waste solution with a specific activity between $1.5 \times 10^{-6}$ and $2 \mathrm{Ci} / \mathrm{gal}$ and referred to in this report as ILW) is generated by a number of processes and discharged to the ILW waste collection system. This system includes twenty-one stainless steel monitoring tanks located near the various sources generating the waste. A heel of caustic solution is kept in each tank so that any acids that are discharged to the waste collection system will be neutralized and will not corrode the tank or other parts of the system. At intervals the contents of each collection tank are pumped or jetted to a waste collection manifold, which presently drains to the ORNL Tank Farm - a group of six Gunite (sprayed concrete) tanks with a total capacity of about one million gallons. The waste solution that is collected in these tanks is concentrated by evaporation. Unconcentrated waste solution is pumped from the two or three Gunite tanks that are used to collect this waste to the evaporator. The specific activity of the evaporator condensate is usually less than $1.5 \times 10^{-6} \mathrm{Ci} / \mathrm{gal}$ and this stream is sent to the Process Waste Treatment Plant for further treatment before discharge to a nearby stream. The evaporator concentrate (concentrated by a factor of about 25) is accumulated in one of the Gunite tanks not used for storage of unconcentrated waste. For the past eight years the accumulated concentrate has periodically been pumped to the shale fracturing facility in Melton Valley, mixed with cement, and injected into a shale formation at an approximate depth of $900 \mathrm{ft}$. About 80,000 gal per year of concentrated waste solution is generated at ORNL. This solution is alkaline and the major constituent is $\mathrm{NaNO}_{3}$, but many other ions are also present. The composition and concentration of this solution changes appreciably with time.

Those chemical species that are insoluble in alkaline solutions are precipitated when the waste solution is neutralized. These solids settle in the Gunite tanks, and, in the thirty years these tanks have been in use, have formed a layer of sludge in the bottom of each tank. The current accumulation of this sludge totals about 400,000 gal. It contains the bulk of 
ORNL-DWG 63-3830

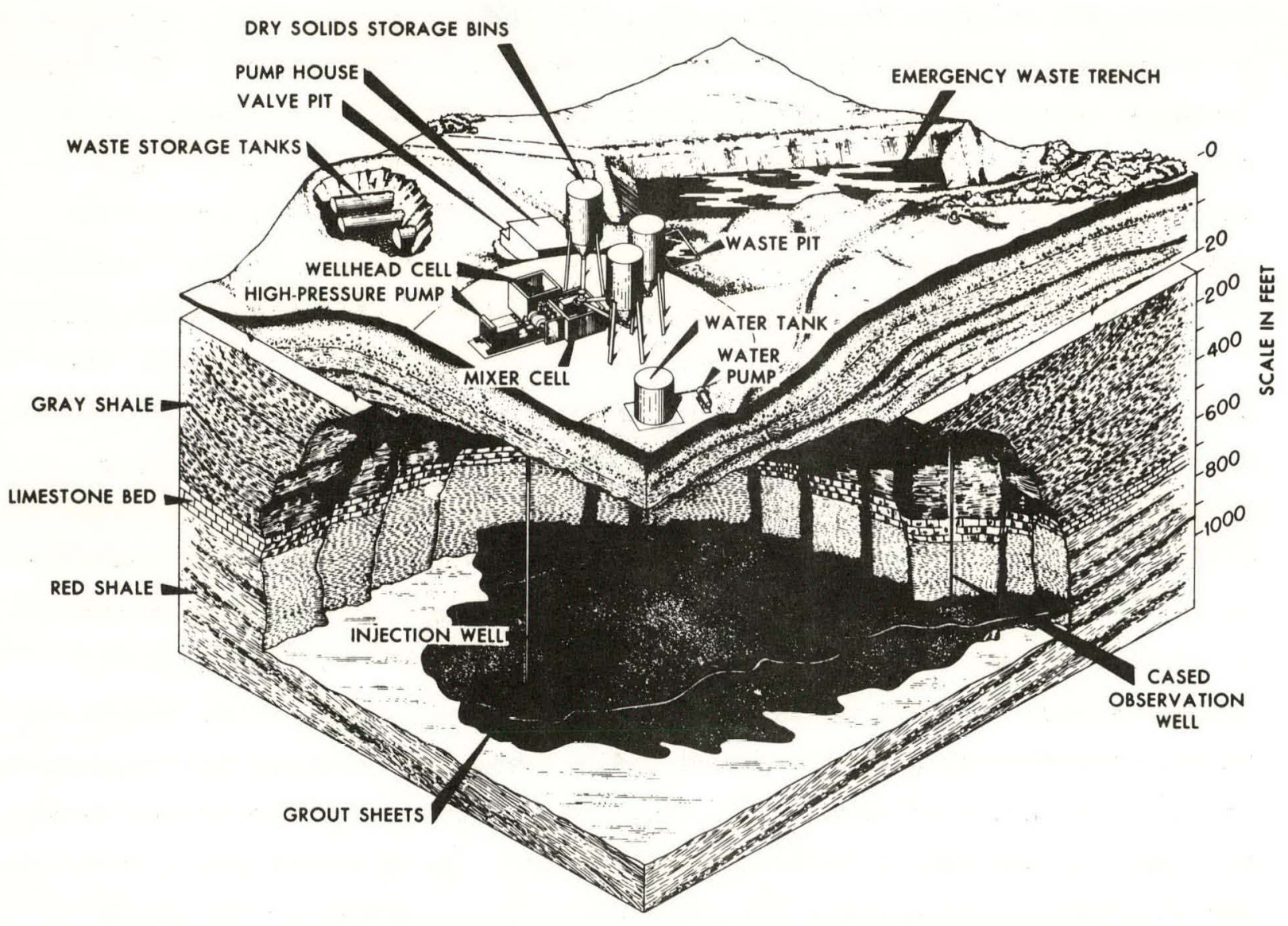

ORNL FRACTURING DISPOSAL PILOT PLANT

Figure 1 
the ${ }^{90} \mathrm{Sr}$ and the actinides that have been discharged to the waste system an estimated 500,000 to 1.5 milition $\mathrm{Ci}$ of ${ }^{90} \mathrm{Sr}, 12,000 \mathrm{Ci}$ of ${ }^{244} \mathrm{Cm}$, and 250 to $310 \mathrm{Ci}$ of ${ }^{239} \mathrm{Pu}$. Thịs sludge also contains about 70 tons of depleted uranium and about 40 tons of thorium.

$\dot{A}$ series of modifications to the ORNL waste handing system has recently been funded. These modifications will consist of the addition of $a$. second, waste evaporator in parallel to the existing evaporator, new evaporator feed and concentrate hold tanks, a new waste transfer line to the Melton Valley facilitles, and eight new waste storage tanks in Melton Valley with a total capacity of $400,000 \mathrm{gal}^{2}$ A sketch of this system is shown in Fig; 20: With this system the Gunite storage tanks will be bypassed; the waste solution will be fed directly to the evaporator feed tank and the : concentrated bottoms w1l1 be transferred to the new waste storage tanks in Melton Valley and stored there. Newly precipitated sludge will accumulate in the new evaporator feed tank as it has in the old Gunite tanks; it is . planned to install slurry suspension and pumping equipment so that the slurries that settle in the evaporator tanks can be transferred to the waste storage tanks in Melton Valley for subsequent processing and storage or ultimate disposal.: At some future date the sludge currently in the Gunite tanks w111 also be resuspended and pumped to the Melton Valley storage tanks.

The, main operation area of Oak Ridge National Laboratory is loçated in Bethel Valley in the south central part of the Oak Ridge ERDA reservation. Certain Laboratory operations, including the existing and proposed shale fracturing plants, are: Focated in Melton Valley, about a mile to the southeast of the main area. The location of the proposed new shale fracturing facility. and its relationship to other Laboratory, facilities is shown in Fig. 3. This figure also shows the location of the existing Gunite tanks, the waste evaporator, the new waste transfer pipeline and the existing. shale fracturing facility。 


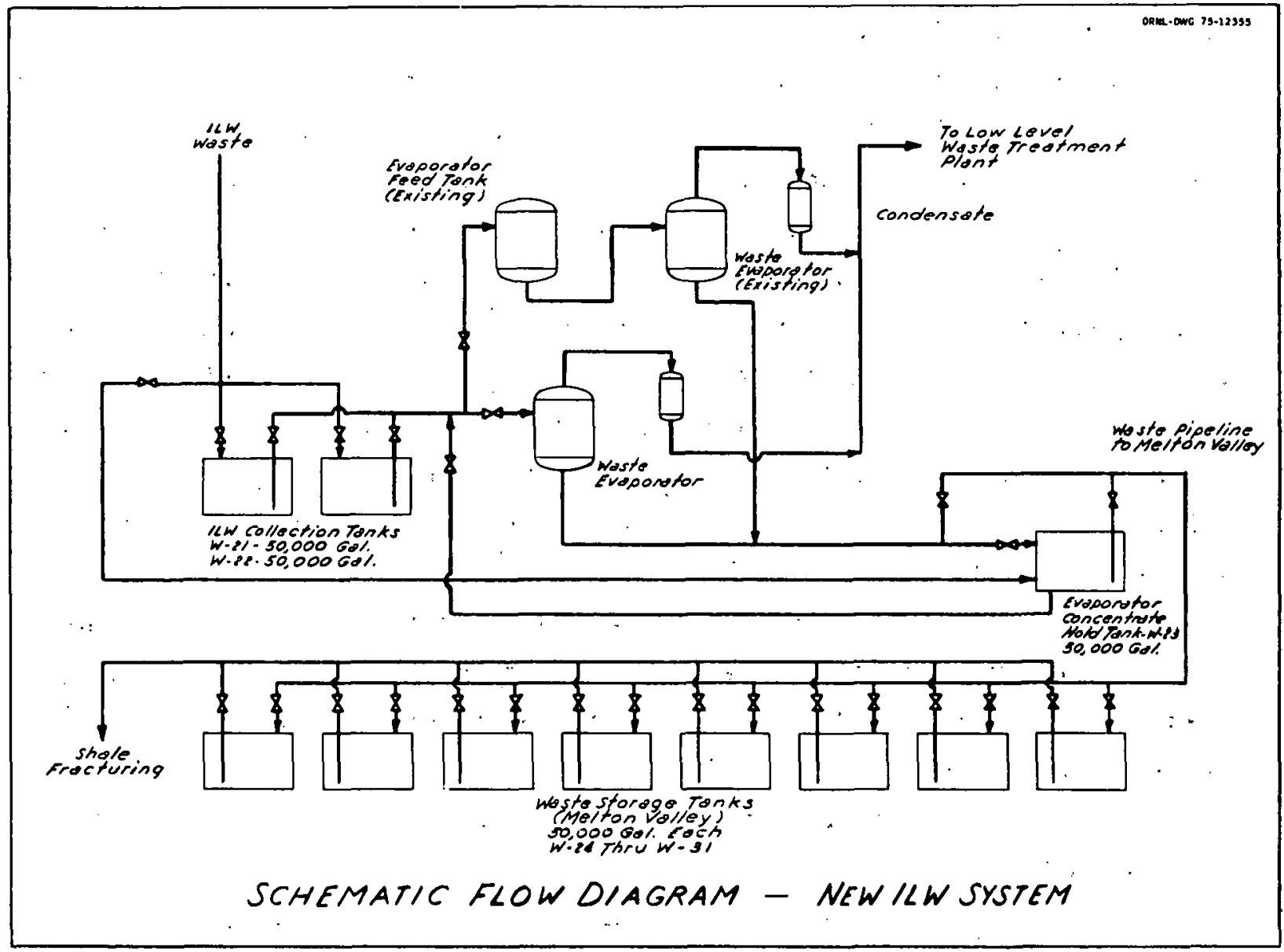

Figure 2 
ORNL DWG. 73-3978 R2

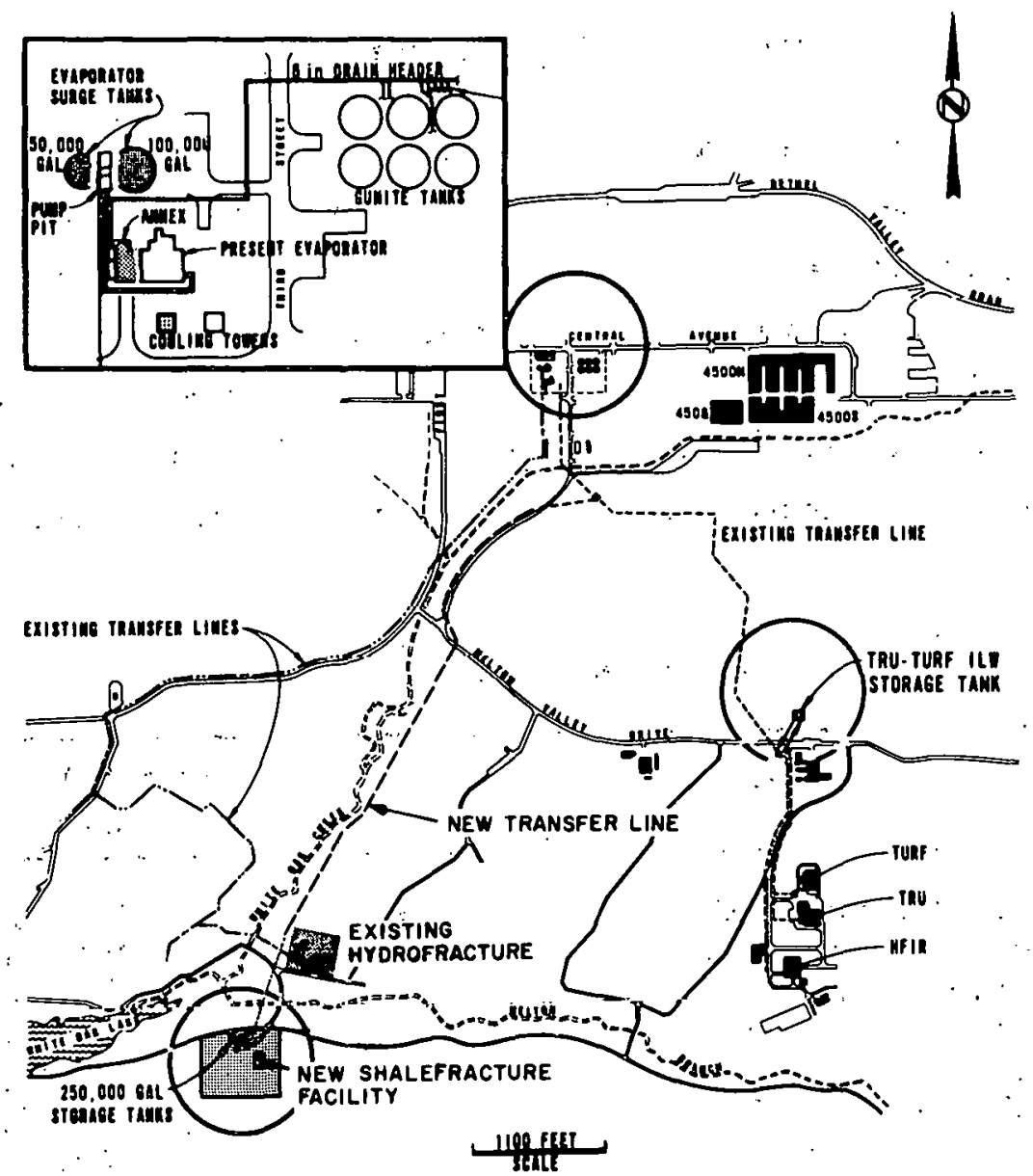

MODIFICATIONS TO ORNL LIQUID WASTE SYSTEM

Figure 3 


\subsection{WASTE STREAMS}

The waste streams that must be handled by, any processing system that is installed at ORNL are the intermediate level liquid waste (ILW), the precipitated ILW sludge already in storage in the Gunite tanks and the ILW sludge that will be accumulated in the new tankage by routine operations. Each of these waste streams is considered in detail in the following sections.

\subsection{Intermediate Level Waste (ILW)}

The volumes of unconcentrated ILW generated by various facilities at ORNL over the past year and which are expected to be typical of future years operations are given in Table 2. The seven facilities that are listed generate about $75 \%$ of the total ILW; the remaining $25 \%$ is generated at fifteen other small facilities. No routine effort is made to determine the chemical or radionuclide content of most of these waste streams. It is known; however, that these compositions vary considerably from time to time。

Table 2. Generated Volumes of ILW

\begin{tabular}{lr}
\hline \multicolumn{1}{c}{ Facility } & $\begin{array}{r}\text { Yearly.Volume } \\
\text { (gal) }\end{array}$ \\
\hline Chemical Separations Facility (B1dg。3019) & 287,000 \\
Fission Product Development Lab & 227,100 \\
Oak Ridge Research Reactor & 313,400 \\
High Flux Isotope Reactor. & 202,600 \\
Radioisotopes. & 193,500 \\
Research Lab (B1dg。 4500) & 177,600 \\
Transuranium Facility & 40,000 \\
Subtotal & $1,441,200$ \\
Miscellaneous Sma1l:Facilities & 475,800 \\
Total & $1,917,000$ \\
Concentrate After Evaporation & 280,000 \\
\hline
\end{tabular}


The Ionic analysis of four recently analyzed concentrated iLW waste solutions is given in Table 3. Nominal chemical compositions based on : these analyses are given in Table 40.-It is apparent that the composition changes considerably between batches, both in total ionic strength and in relative proportions of the various ions.: The concentration of aluminum, for instance, varies by a factor of 30 , the concentration of chloride varies. by a factor of 5 , and the concentration-of sodium varies by a factor of 3 .

Table 3. Ionic Analyses of : Four ILW Solutions

\begin{tabular}{|c|c|c|c|c|c|}
\hline 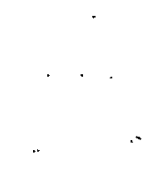 & $\begin{array}{c}\text { Tank: } \\
\text { W-7 Waste } \\
\text { Septo } 197: 2 \\
\text { (mols/l) }\end{array}$ & $\begin{array}{c}\text { Tank } \\
\text { W-8 Waste } \\
\text { Sept. } 1972 \\
(\text { mols/l) }\end{array}$ & & $\begin{array}{c}\text { Tank } \\
\text { W-9. Waste } \\
\text { Sept } 197: 2: \\
(\text { mols } / \ell)\end{array}$ & $\begin{array}{c}\text { Tank } \\
\text { W-10 Waste } \\
\text { Sept } 1972 \\
\text { (mols/l) }\end{array}$ \\
\hline $\mathrm{Na}^{+}$ & 1,66 & 1.24 & & 0.57 & 0.59 \\
\hline $\mathrm{Al}^{+} 3$ & 0.007 & 0.037 & $=$ & 0.002 & 0.0011 \\
\hline $\mathrm{NH}_{4}{ }^{+}$ & 0.003 & 0.03 & & 0.0443 & 0.050 \\
\hline$\dot{\mathrm{O}} \mathrm{H}^{-}$ & 0.18 & 0.28 & & 0.15 & 0.16 \\
\hline $\mathrm{NO}_{3}^{-}$ & 0.84 & 1.03 & & 0.30 & 0.30 \\
\hline $\mathrm{Cl}^{-}$ & 0.093 & 0.217 & & 0.049 & 0.044 \\
\hline $\mathrm{SO}_{4}{ }^{-2}$ & 0.094 & 0.183 & & 0.111 & 0.125 \\
\hline $\mathrm{CO}_{3}-2$ & 0.193 & 0.288 & & 0.093 & 0.10 \\
\hline
\end{tabular}

Table 4\% Nominal. Chemical Composition of Four Waste Solutions

\begin{tabular}{|c|c|c|c|c|}
\hline & $\begin{array}{c}\text { Tank } \\
\text { W-7 Waste } \\
(\text { mols } / \ell)\end{array}$ & & $\begin{array}{c}\text { Tank } \\
\text { W-8 Waste } \\
\therefore(\text { mols } / \ell)\end{array}$ & $\begin{array}{c}\text { Tank. } \\
W-9 \text { and } W-10 \\
(\operatorname{mols} / \ell)\end{array}$ \\
\hline $\mathrm{NaOH}$ & 0,18 & & 0.23. & 0.08 \\
\hline $\mathrm{NaNO}_{3}$ & 0.81 & & 1.0 & 0.2 .95 \\
\hline $\mathrm{Na}_{2} \mathrm{SO}_{4}$ & 0.094 & & 0.183 & 0.098 \\
\hline $\mathrm{Al}\left(\mathrm{NO}_{3}\right)_{3}$ & 0.0074 & & 0.037 & 0.0016 \\
\hline $\mathrm{NH}_{4} \mathrm{NO}_{3}$ & 0.003 & . & 0.03. & - \\
\hline $\mathrm{NaCl}$ & 0.093 & & 0.217 & $: \because-$ \\
\hline $\mathrm{NH}_{4} \mathrm{Cl}$ & - & & - & 0.05 \\
\hline $\mathrm{Na}_{2} \mathrm{CO}_{3}$ & 0.19 & & 0.288. & 0.136 \\
\hline
\end{tabular}


The concentrations of selected radionuclides in these four. batches of waste solution are given in Table $50^{3}$ Also given for comparison are average and maximum values of the concentrations observed in these waste solutions over a six-year period. It has been observed that the waste solutions contain a small quantity (about $0.5 \%$ ) of suspended solids... These solids contain about half of the ${ }^{60} \mathrm{Co}, 97 \%$ of the ${ }^{90} \mathrm{Sr}$, and virtually all of the $2{ }^{39} \mathrm{Pu}$ and ${ }^{244} \mathrm{Cm}$ in the waste solution. The aqueous part of the waste solution contains $98 \%$ of the ${ }^{137} \mathrm{Cs}, 90 \%$ of the ${ }^{106} \mathrm{Ru}$, and about $50 \%$ of the ${ }^{60} \mathrm{Co}$.

Table 5. Radiochemical Analyses of Waste Solutions

\begin{tabular}{|c|c|c|c|c|c|}
\hline \multirow{2}{*}{ Constituent } & \multicolumn{5}{|c|}{ Compositions, $\mathrm{Ci} / \mathrm{gal}$} \\
\hline & $\begin{array}{c}\text { Tank } \\
\text { W-7 Waste }\end{array}$ & $\begin{array}{c}\text { Tank } \\
\text { W-8 Waste }\end{array}$ & $\begin{array}{c}\text { Tank } \\
W-9 \& W-10\end{array}$ & Average* & Maximum* \\
\hline $\begin{array}{l}90 \mathrm{Sr} \\
137 \mathrm{Cs} \\
106 \mathrm{Ru} \\
244 \mathrm{Cm} \\
239 \mathrm{Pu} . \\
60 \mathrm{Co}\end{array}$ & $\begin{array}{c}3.38 \times 10^{-3} \\
0.342 \\
5.5 \times 10^{-3} \\
8.25 \times 10^{-5} \\
\text { none. } \\
\text { n.a. }\end{array}$ & $\begin{array}{c}\text { none } \\
0.38 \\
0.035 \\
\text { none } \\
5.2 \times 10^{-6} \\
\text { n.a. }\end{array}$ & $\begin{array}{l}0.017 .4 \\
0.206 \\
7.1 \times 10^{-3} \\
3.7 \times 10^{-4} \\
\text { none } \\
7 \times 10^{-4}\end{array}$ & $\begin{array}{l}0.031 .6 \\
0.48 \\
6.3 \times 10^{-3} \\
5.2 \times 10^{-4} \\
7.5 \times 10^{-6} \\
1.2 \times 10^{-3}\end{array}$ & $\begin{array}{c}0.11 \\
1.12 \\
0.035 \\
1.97 \times 10^{-3} \\
2.1 \times 10^{-5} \\
2.5 \times 10^{-3}\end{array}$ \\
\hline
\end{tabular}

* Based on analyses of 11 waste solutions.

$n_{0} a_{0}=$ not available.

\subsection{ILW.Sludge}

This sludge is the precipitate formed by the neutralization of the ILW. It contains the bulk of the ${ }^{90} \mathrm{Sr}$ and the transuranics that are in the ILW. This sludge slowly settles to the bottom of any waste storage tank in which It is held and is retained there as the ILW is removed for processing. The current inventory of ILW sludge is approximately 400,000 gal and the current generation rate is approximately $10,000 \mathrm{gal} / \mathrm{yr}$.

Available information on the chemical and physical properties of the sludge is given.in Table 6. The samples from which these data were obtained were taken from a limited area near the bottom of tanks that are $50 \mathrm{ft}$ in diameter; they are probably not representative of the sludge as a whole. Currently generated sludge, for instance, contains little uranium or thorium and probably has a correspondingly lower density. A program is presently in progress to obtain a more representative sample of the sludges in each tank. 
Table 6. Properties of Sludge

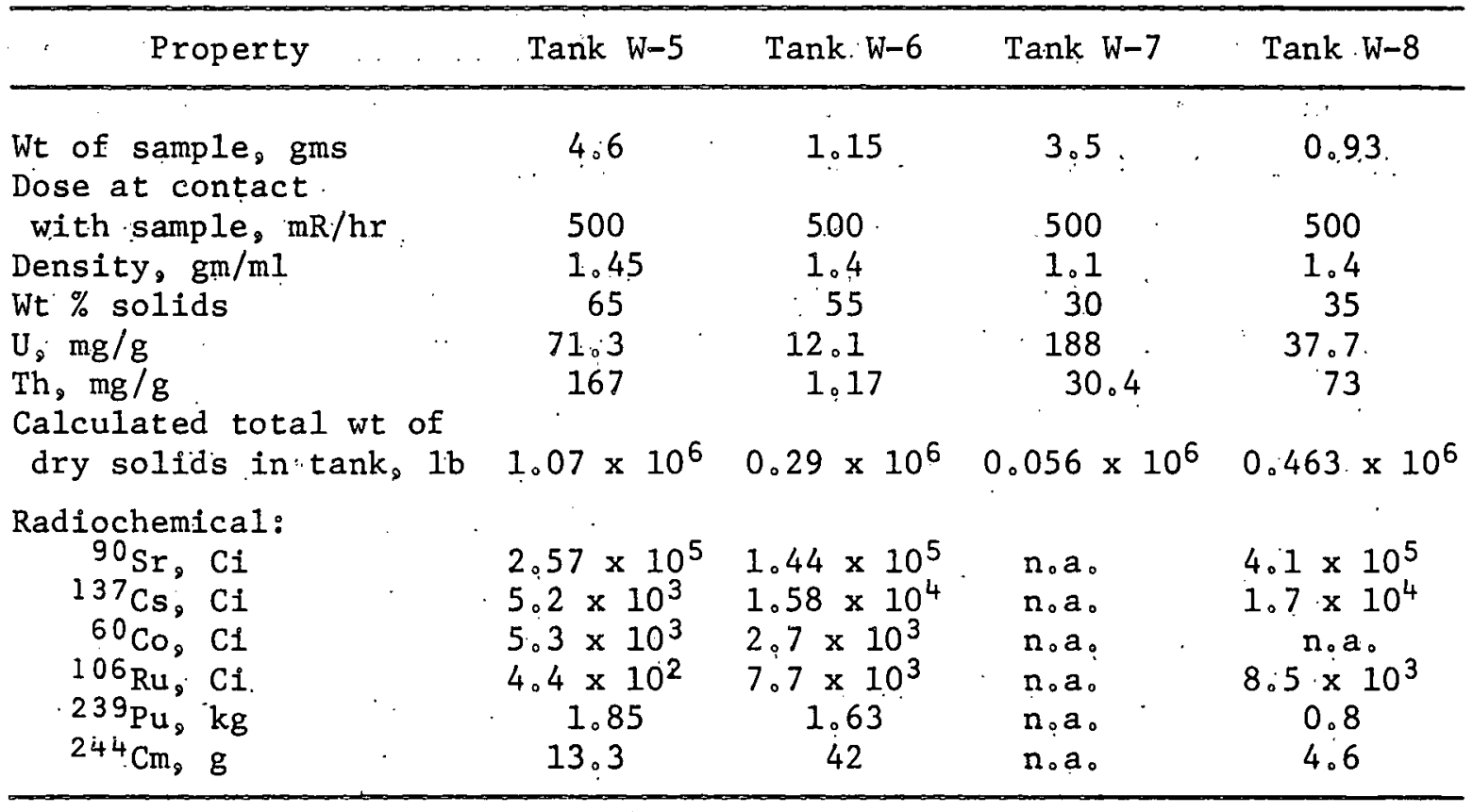

$n_{\circ} a_{0}=$ not avallable.

The samples of sludge that were obtained resembled loose and somewhat sloppy clays. Slurries of these samples with water settled fairly quickly to a quasi-stable suspension with a volume 1.5 to 4 times the original volume. Further settling was quite slow - weeks would be required for any significant change.

Some samples of these sludges were washed several times with water and dried. No significant volume change was observed: A similar treatment to sludges at Savannah River and elsewhere has resulted in very large volume changes; the ORNL sludges are atypical in this respect。

\subsection{Organics}

No separate waste collection system for radioactive órganic solvents exists at ORNL。The small quantities (about $1000 \mathrm{gal} / \mathrm{yr}$ ) of these waste organic solvents that are generated at the Laboratory are disposed of in the ILW system." The more volatile of these solvents are stripped from the ILW in the waste evaporator and are discharged with the evaporator condensate to the Process Waste Treatment Facility. These organics are essentially decontaminated. The less volatile solvents will remain with the concentrated. ILW and will be disposed of with this stream. 


\subsection{Future Wastes}

Several pilot plant programs that have been proposed for ORNL have the potential for generating waste solutions with a higher specific activity than the ORNL intermediate level waste has had in the past. Some of these programs such as the LMFBR reprocessing plant, propose to include processes that will immobilize all waste streams that are generated. The future effect of such a facility on the ORNL waste system would be minimal. Other programs may not have such capability, however, and may contribute substantial quantities of radionuclides to the ORNL waste system. If the quantity of these radionuclides is not excessive, such waste could be fed directly or almost.directly to the ILW system. If the quantity and concentration of radionuclides are high, howevier, the wastes would be stored in high level, waste storage tanks unt1l the isotopes with short half-lives had decayed (at least five years)。After this time these wastes or some part of them could probably be processed by the ORNL waste. syṣtem. It may not be desirable to process these wastes in this way, but the capability would exist.

Future pilot plant wastes that may be processed by the ORNL waste system would be neutralized if necessary, diluted to the desired specific activity, and pumped to one of the waste storage tanks in Melton Valley. In this tank the insoluble chemical compounds formed by the neutralization reactions 'would settle to form a sludge layer. This layer would contain those radionuclides that are insoluble in alkaline solutions $-{ }^{90} \mathrm{Sr},{ }^{144} \mathrm{Ce}$, ${ }^{147} \mathrm{Pm}$. The ${ }^{137} \mathrm{Cs}$ and ${ }^{106} \mathrm{Ru}$ would remain in solution。 It is anticipated that the settled sludge volume would be about $12 \%$ of the original solution volume.

For this study it has been assumed that: a diluted, neutralized, and well stirred waste that might be processed by an ORNL facility would have a specific activity of $20 \mathrm{Cl} / \mathrm{gal}$ of long-lived $\beta-\gamma$ emitters - about $5 \mathrm{Ci} / \mathrm{gal}$ of ${ }^{137} \mathrm{Cs}, 5 \mathrm{Ci} / \mathrm{gal}$ of ${ }^{90} \mathrm{Sr}, 6.9 \mathrm{Ci} / \mathrm{gal}$ of ${ }^{147} \mathrm{Pm}, 2.8 \mathrm{Ci} / \mathrm{gal}$ of ${ }^{144} \mathrm{Ce}$, and $0.3 \mathrm{Ci} / \mathrm{gal}$ of ${ }^{106} \mathrm{Ru}$. The complete assumed radiochemical composition is, given in Table, 7 ? 
Table 7. Waste : Stream Composition - Design Basis

\begin{tabular}{|c|c|c|c|c|}
\hline$:$ & $\begin{array}{c}\text { ILW } \\
\text { Concentrate }\end{array}$ & Current Sludge & $\begin{array}{l}\text { Inventory } \\
\text { Sludge }\end{array}$ & $\begin{array}{l}\text { Diluted } \\
\text { Pilot Plant } \\
\text { :Waste. }\end{array}$ \\
\hline Volume, gal/yr & 80,000 & 10,000 & 40,000 & Unknown \\
\hline Total salt molarity & $1.2 \mathrm{M}$ & - & - & Unknown. \\
\hline$\%$ suspended solids & 0.5 & 40. & 50 & $6 \%$ \\
\hline${ }^{90} \mathrm{Sr}_{2} \mathrm{Cl} / \mathrm{gal}$ & 0.1 & 1.6 & .2 .0 & 5.0 \\
\hline $90 \mathrm{Y},{ }^{2} \mathrm{Ci} / \mathrm{gal}$ & 0,1 & 1.6 & 2.0 & 5.0 \\
\hline $137 \stackrel{\mathrm{C} s}{\mathrm{C}}, \mathrm{Ci} / \mathrm{gal}$ & 1.0 & 0.16 & 0.2 & 5.0 \\
\hline $137 \mathrm{mBa}_{\mathrm{Ba}} \mathrm{Ci} / \mathrm{gal}$ & 0.92 & 0.15 & 0.18 & 4.6 \\
\hline${ }^{144} \mathrm{Ce}, \mathrm{Ci} / \mathrm{gal}$ & - & - & - & 2.8 \\
\hline${ }^{144} \mathrm{Pr}_{8} \quad \mathrm{Ci} / \mathrm{gal}$ & - & - & - & 2.8 \\
\hline $147 \mathrm{Pm}, \mathrm{Ci} / \mathrm{gal}$ & - & - & - & 6.9 \\
\hline $60 \mathrm{Co}^{6} \mathrm{Cl} / \mathrm{gal}$ & $2 \times 10^{-3}$ & 0.08 & 0.1 & - \\
\hline $106 \mathrm{Ru}, \mathrm{Ci} / \mathrm{ga} 1$ & 0.035 & $=0.04$ & 0.05 & 0.3 \\
\hline $106 \mathrm{Rh}, \mathrm{Ci} / \mathrm{gal}$ & 0.035 & 0.04 & 0.05 & 0.3 \\
\hline $233^{\mathrm{U}}, \mathrm{Cl} / \mathrm{gal}$ & - & $2 \times 10^{-4}$ & - & - \\
\hline $239 \mathrm{Pu}, \mathrm{Cl} / \mathrm{gal}$ & $2 \times 10^{-5}$ & $6.4 \times 10^{-4}$ & $8 \times 10^{-4}$ & - \\
\hline $24{ }^{4} \mathrm{Cm}, \mathrm{CI} / \mathrm{gal}$ & $1 \times 10^{-3}$ & $2.4 \times 10^{-2}$ & $3 \times 10^{-2}$ & - \\
\hline
\end{tabular}

\subsection{Design Basis}

An average composition and yearly volume has been assumed for each of the several waste streams of concern to this study - the ILW the currently generated ILW sludge, and the ILW sludge in inventory. These values are given in Table 7, The sludges would have to be diluted by a factor of 4 or 5 before they could be resuspended and transported through the waste handling system, but the sludge volumes given in Table 7 are for sludge "as is." A ten-year processing period is assumed for the 400,000 gal of sludge in inventory in order that the several alternative waste fixation processes can be compared at a common processing rate. The sludge processing rate for a shale fracturing facility could be considerably faster than this assumed rate without any significant penalty; a total sludge processing time of one to two years would probably be quite feasible: $A$ postulated radionuclide composition for a diluted future pilot plant waste solution is also given in Table 7. No meaningful estimate can be given at this time for the yearly volume of this waste. 
The long-term hazard associated with these wastes is relatively low, since the wastes contain only small quantitles of ${ }^{23{ }^{9}} \mathrm{Pu}$ or any other emitting radionuclide with a long half-life. The most significant nuclides, ${ }^{90} \mathrm{Sr}$ and ${ }^{137} \mathrm{Cs}$, will decay to insignificant levels in 500 to 700 years, a relatively short time when compared to the very long expected isolation time. The ${ }^{239} \mathrm{Pu}$ w1ll remain in the formation, but its concentration in the disposal formation at the conclusion of the waste injection operations will average less than $0.1 \mu \mathrm{Ci} / \mathrm{kg}$. This is within the range of naturally occurring ${ }^{226} \mathrm{Ra}$, a radionuclide with a hazard roughly comparable to that of ${ }^{239} \mathrm{Pu}$.

\subsection{FORM AND PLACEMENT OF WASTE}

\subsection{Properties of Waste Form}

In the shale fracturing process the waste solution is combined with a clay cement $\mathrm{mix}$ and the resulting grout is pumped into an isolated shale formation and allowed to set. The requirements of this process set several stringent criteria for the properties of the grouts that can be used. They must be compatible with the waste solutions that are injected, must be pumpable for extended periods. ( $24 \mathrm{hrs}$ ) of time, and must retain virtually all the assoclated water when they set. Another desirable characteristic is a relatively. low leach.rate. The blend of solids that, when mixed with ORNL waste solutions, has been found to produce grouts with these properties contain cement, a retarder to delay the setting of the grout, attapulgite clay to retain excess water," a second clay to retain cesium, and fly ash to retain strontium. The proportions of the different ingredients can be adjusted to allow for considerable variation in the composition or concentration of the waste solution being injected. A typical recent composition is shown in Table 8 .

Table 8. Composition of Dry Solids Mix

\begin{tabular}{lc}
\hline Ingredient & Wt \% \\
\hline Cement (Type 1) & 38.5 \\
Fly Ash & 38.5 \\
Attapuigite & 15.4 \\
Shale & 7.7 \\
Retarder & 0.05 \\
\hline
\end{tabular}


This dry solids mix is : usually blended.with liquid waste solution at a solids to liquid ratio of between 6 and 9 lbs per gallon. The grout produced has a density of about 12 lbs per gallon and an apparent viscosity of about $40 \mathrm{cp}$. The volume ratio of grout to liquid waste is approximately 1.4 .

Unt:1l quite recently the additive that has been used to retain cesium In the grout has been Grundite (an 1llitic clay)。 Recent teș ș have shown, however, that several other additives have a much greater affinity for cesium than does Grundite (Fig。 4) - Pottery clay (American Art Clay Co., Indian Red clay) performs well, but the best material found to date is local Conasauga shale。

Leach rates of cesium, strontium, plutonium, and curium from clay cement grouts have been determined: ${ }^{4}$ These tests indicated a rate of leaching of cesium from a grout cured 28 days and leached for 100 days of 1.08 $\times 10^{-3} \mathrm{gm} / \mathrm{cm}^{2}$-day if the grout contained illite for cesium retention, 1.75 . $x 10^{-5} \mathrm{gm} / \mathrm{cm}^{2}$-day if the grout contained pottery clay for cesium retention, and $7.1 \times 10^{-6} \mathrm{gm} / \mathrm{cm}^{2}$-day if the grout contained ground Conasauga shale. The vastly improved retention of cesium that can be produced by a relatively slight change in mix composition 1llustrates particularly well how the grout properties can be varied to meet specific requirements. The strontium leach rate of $3.2 \times 10^{-5} \mathrm{gm} / \mathrm{cm}^{2}$-day can most probably be significantly reduced by minor mix modifications: The leach rate for curium has been found to be $1.7 \times 10^{-7} \mathrm{gm} / \mathrm{cm}^{2}$-day and the leach :rate for plutonium has been found to be $1.4 \times 10^{-7} \mathrm{gm} / \mathrm{cm}^{2}-$ day。

The leach rates given above were determined for a grout :sample made from a waste solution that was about $1 \mathrm{M}$ in total salt content. Recent tests have indicated that grouts made from 3 to $4 \mathrm{M}$ salt solutions retain the ${ }^{137} \mathrm{Cs}$ equally well: 5 This finding, if verified for other radionuclides; would. make the further concentration of ILW solution prior to disposal a feasible option and would have some effect on process costs. The applicability of clay cement or shale cement mixes to sludge incorporation also needs verification. No experimental work has been done with ORNi sludges, but no reason is known why they should be incompatible with the shale cement mixes. 


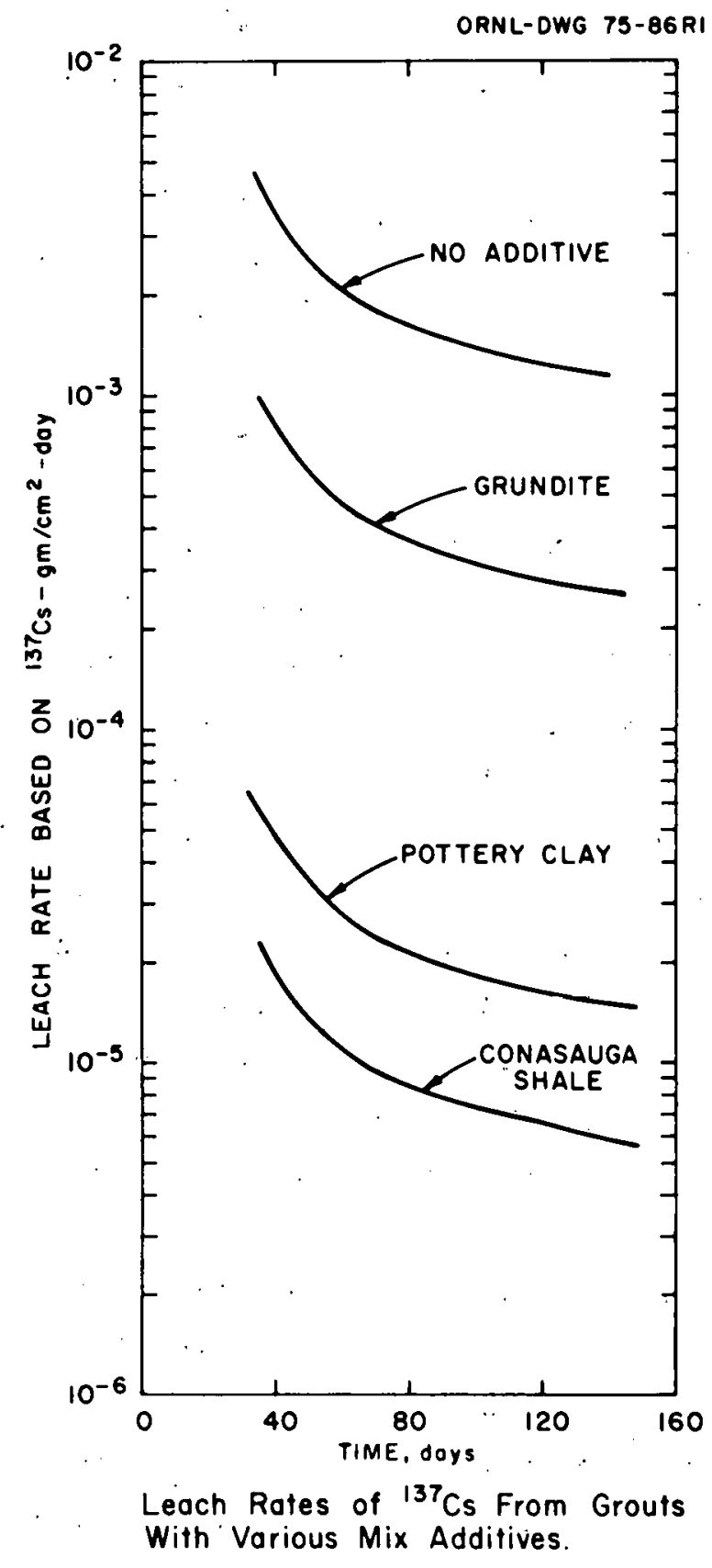

Figure 4 


\subsection{Placement of Waste Form}

Freshly mixed waste grout is injected under pressure into a carefully selected bedded shale formation. The injected grout spreads out from the injection well as a thin sheet that is about $1 / 2$ in. thick and several hundred ft across. Figure 5 shows a core of a grout sheet from one such injection. In this particular core the grout sheet occurs in several layers that are approximately parallel and a few inches apart. The tendency of the shale to break along bedding planes is apparent in this picture。

The essential feature of the shale fracturing process is the fixation of the radionuclides in a geologic formation that is isolated from contact with the surface environment. Several independent lines of evidence indicate that the formations into which the injections are made are quite isolated and have been so for millennia. The shales in the disposal zone contain appreciable amounts of dispersed sodium chloride and small amounts of trapped gases (mainly methane and nitrogen), strong evidence that this formation is not in contact with the surface or near-surface environment. In addition, microscopic examination of cores showed no indication of water flow below a depth of about $200 \mathrm{ft}$, laboratory tests of cores showed that permeabilities are quite low, and measurement of thermal gradients in test wells indicated little or no significant movement of groundwater below 200 $f t .6$

There are some additional features of the shale fracturing process that will provide continued containment of the radionuclides even if the isolation of the disposal formation should be lost by some mechanism. The leach rate of significant radionuclides from the set grout is quite low and the loss of radionuclides from the grout sheet would be slow, even if some water did reach the formation. Also, the shale formation into which injections are made has a high ion exchange capacity and would tend to retain any radionuclides that might be leached from a grout sheet. Some experimental tests have indicated that net migration rates of ${ }^{137} \mathrm{Cs}$ and ${ }^{90} \mathrm{Sr}$ in Conasauga shale will be in the order of a few inches or tenths of an inch per year - so low that none of these radionuclides could reach the surface environment. 


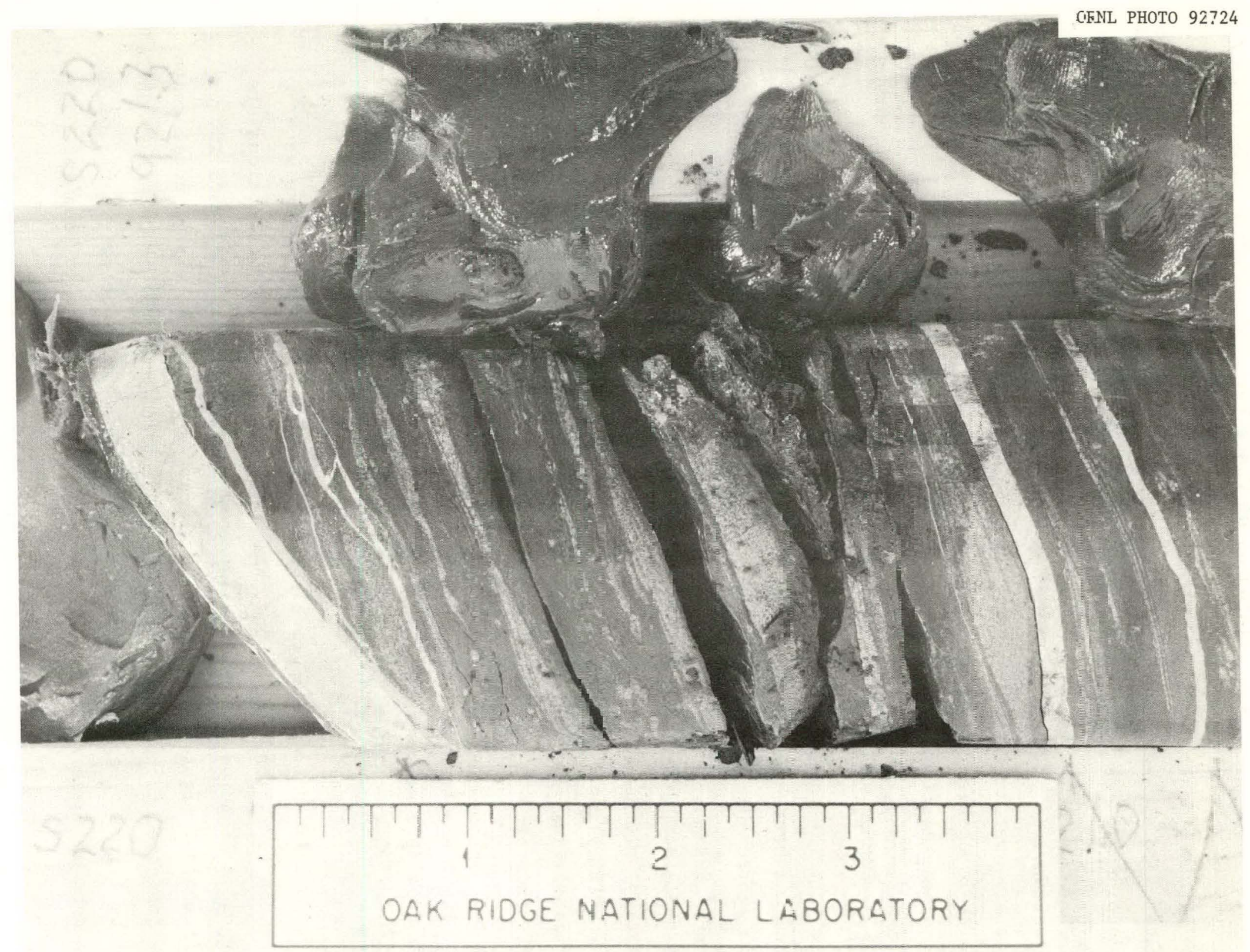

Figure 5 


\subsection{Description of Disposal Formation}

\section{$4.3 .1 \cdot \underline{\text { Geology }}$}

Oak Ridge is located in the "Valley and Ridge" physiographic province, a belt of faulted and folded rock which lies between the "Blue Ridge" subdivision of the Appalachian Plateau to the southeast and the Cumberland Plateau to the northwest. The province is about 50 miles wide in the Oak Ridge area, and is marked by a serles of great overthrust.faults, in each of whlch a layer of rock very roughly two miles thick has moved as much as several tens of miles to the northwest, overriding the similar sheet of rock, in front of $i t$, and in turn overridden by the sheet behind it.

Two fault sheets of immediate interest to the work at Oak Ridge are composed of four formations. The oldest is the Rome sandstone; of lower Cambrian age. That part of the upper Rome present in the shale fracturing plant area is largely.composed of beds of hard brittle quartzite 1 . in, to $1 \mathrm{ft}$ thick. The Rome is overlaid by the Conasauga shale, about 2000. ft thick. The bottom $300 \mathrm{ft}$ of the Conasauga, the Pumpkin Valley member, is dense argillaceous shale that is very thin-bedded and dominantly red. This is the unit into which ali the experimental and actual waste injections have been made. The Pumpkin Valley is overlaid by what is probably the Rutledge member of the Conasauga: The so-called Rutledge, about $1000 \mathrm{ft}$ thick, is composed of gray calcareous shale interbedded with generally thin. beds or lenses of limestone. The contact between the Pumpkin Valley and the Rutledge is marked by three thla beds in which limeștone predominates; these beds are useful as stratigraphic reference points.

The diagram of the subsurface geology at the fracturing plant site is shown in Fig. 60. A test well has been drilled to a depth of $3263 \mathrm{ft}$ on a site approximately $300 \mathrm{ft}$ from the present fracturing plant, and $500 \mathrm{ft}$ from the proposed new facility. Cores from this well fixed the depth of the various geologic formations adjacent to the injection site. These data have been analyzed in detail。?

\subsubsection{Hydrology.}

Conasauga shale, the formation into which injections are made; is weathered to a depth of $50 \mathrm{ft}$ or more under the ridges, and to a deptil of 


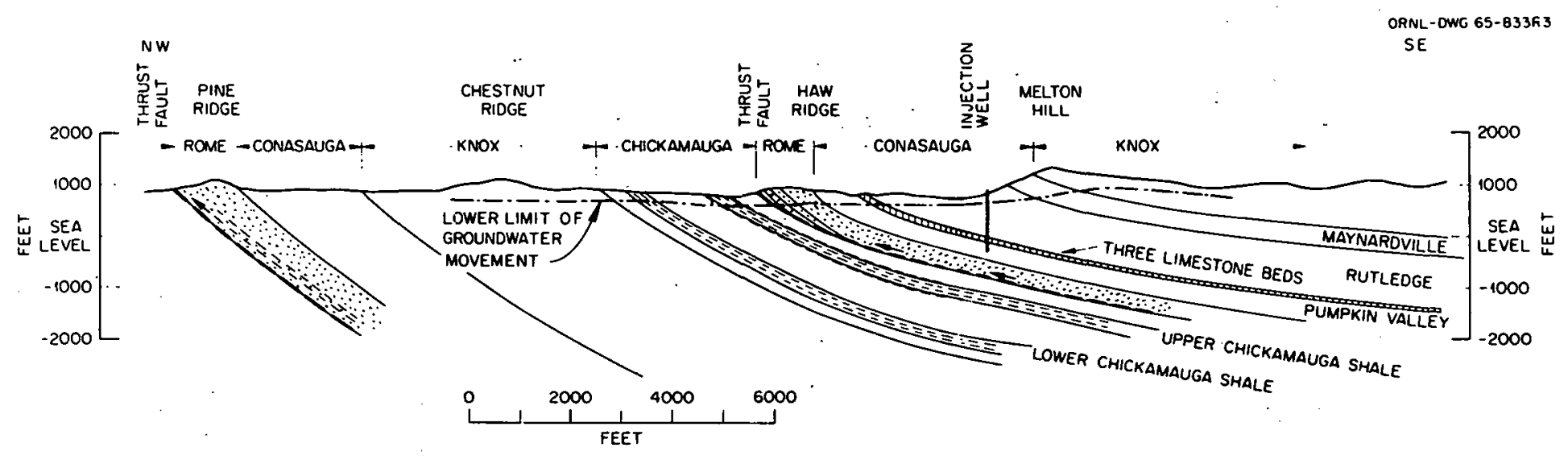

Figure 6 
5 to $10 \mathrm{ft}$ in the valleys. The weathered material is permeable, although only poorly so, and contatns groundwater. Wells drilled in the weathered shale will yield from 2 to $10 \mathrm{gpm}$... There is some very local movement of groundwater in the Conasauga along weathered :joints to depths of 100 or even $200 \mathrm{ft}$, but the amount of water reaching these depths is small and the rate of movement is even smaller. There is no known movement of groundwater below $200 \mathrm{ft}$. Tests of the nine rock cover monitoring wells at the existing site show: that the shale at depths of 500 to $600 \mathrm{ft}$ is quite impermeable. Water is perfodically pumped into theșe wells at a pressure of 75 psi to determine what changes in permeability are occurring in the shale below the cased part of the well; When first tested, some of the wells accepted no measurable quantity of water; the others, would take a gallon or two during the first hour of pumping; but after: that would accept no more。: These low formation permeabilities have not changed appreciably over a ten-yr period.

\section{- 4.4 Test of Disposal Formation}

The proposed location for the new shale fracturing facility is about. $800 \mathrm{ft}$ southwest of the existing facility. Because of its close proximity to the existing facility, it was expected that the underground strata would be similar at the proposed new site to that at the existing facility, and that it would be suitable for shale fracturing disposal operations To verify that the proposed site was suitable, a site proof study was undertaken during FY-74。. This study consisted of drilling an injection well and four monitoring wells, making a test injection of a synthetic grout tagged with radioisotope tracer, and determining the orientation of the resulting grout.sheet. In addition, one of the wells that was drilled for the site proof test was.cored in the depth interval between 700 and $1100 \mathrm{ft}$ for comparison with the geologic.structure that was obtained from similar cores at the existing site. Examination of these core samples and of gamma logs of the injection well and the monttoring. wall at the new site shows. that the stratigraphy. is essentially. the same as that at the existing hydrofracture site, with the main difference being that the dip of the red shale. in the disposal formation is somewhat flatter, $4^{\circ}$ to $10^{\circ}$ to the southeast, at the new site than $1 \mathrm{t}$ is at the old site. 
The four observation: wells and the injection well at the new site were drilled using rotary drilling apparatus to a depth of about $1100 \mathrm{ft}$.' The wells all deviate to the northwest as indicated in Fig. 7. However, they. form a relatively parallel system and are. satisfactory for determining the location of injected grout sheets:

The new injection well was slotted at a depth of about $1090 \mathrm{ft}$. The red shale formation fractured at a pressure of about 2650 psi and the fracture could be propagated at a pressure of about 2200 psi. The test injection, consisting of about 100,000 gal of grout tagged with 20 curies of gold-198, was made on June 14, 19.74。 The injection rate averaged 247 gal per minute at an average pressure at the pump of 2900 psi and at the wellhead about 2400 psi. The average solids content of the injected grout was 8.05 lbs per gal: After the completion of the test injection the four observation wells were logged promptly with a gamma sensitive probe. The grout sheet resulting from the injection was found in the south and west wells. It appeared to have followed the bedding planes as was expected. The logs of the north well were somewhat ambiguous. No evidence of the sheet was found during the logging of the east well. The results of the study indicate that the proposed site for the New Hydrofracture Facility is suitable for hydrofracture disposal operations.

\subsection{WASTE DISPOSAL BY SHALE FRACTURING}

\subsection{Process Description}

In the shale fracturing process the waste solution is mixed with a solids blend of cement and other additives and injected into an impermeable and isolated shale formation. The injection pressure is sufficiently high to propagate a thin horizontal crack in the shale. As the injection of the grout continues, this crack is filled by the grout and is further extended so that a thin, approximately horizontal, grout sheet several hundred feet across is formed during the course of the injection. The grout sets a few hours after completion.of the injection, thereby permanently fixing the radioactive wastes in the shale formation. 


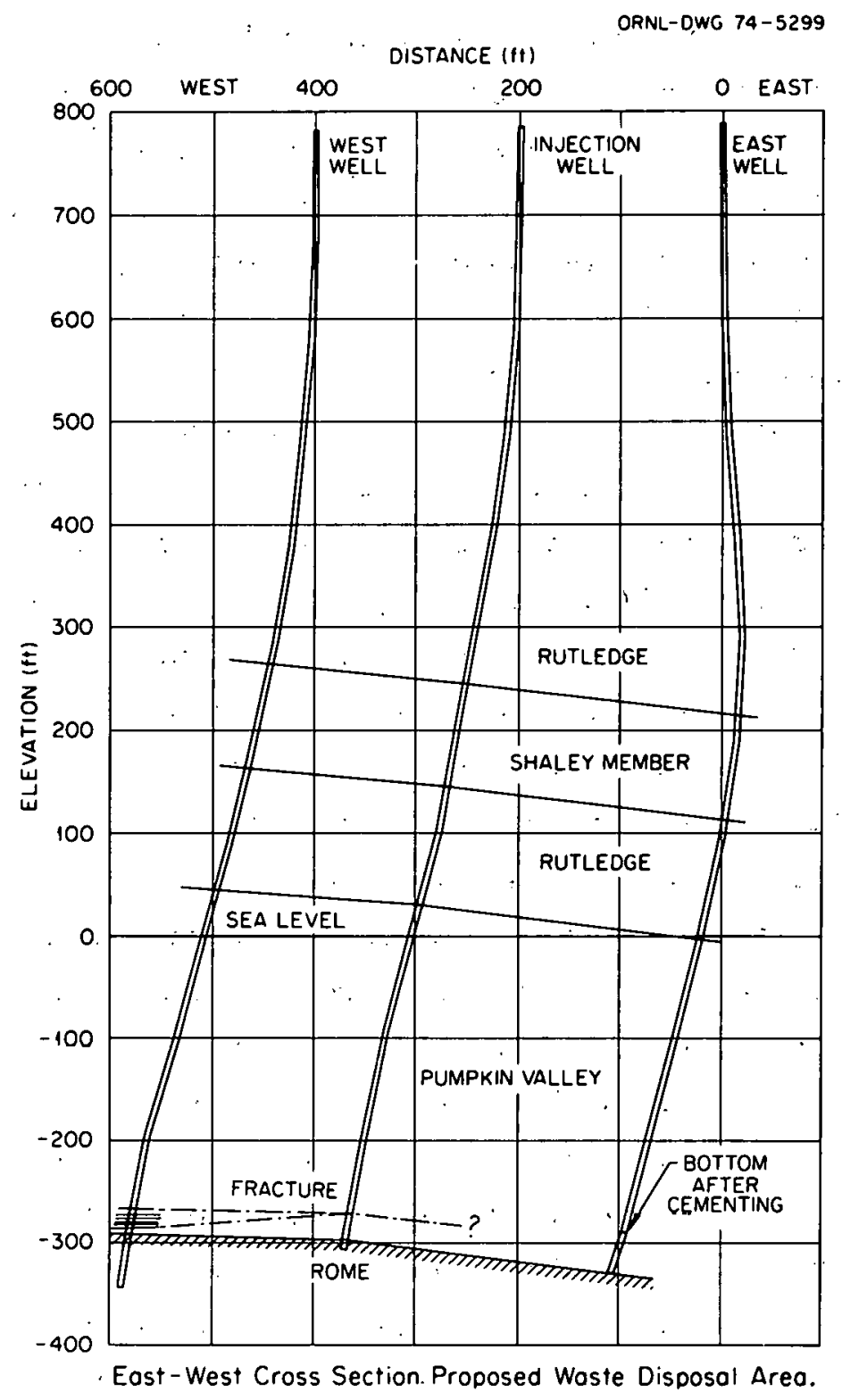

Flgure 7 
An injection facility consists of the injection well, a network of monitoring wells, storage tanks, for the waste solution, storage bins for the dry solids mix, a mixer, a: surge tank, and an injection pump and associated high pressure piping. A standby injection pump is required for each injection; its function is to clear-grout from the injection well and other high pressure piping in the event of failure of the main injection pump. Since this pump need not pump contaminated solutions, it may be rented for the injection. A flow diagram of an injection facility, is shown in Fig. 8. More detailed conceptional drawings are shown in the Appendix.

Three types of wells have been used at the shale fracturing facility an injection well for the injection of waste grout, observation wells for the determination of the orfentation of the grout sheet, and rock cover monitoring wells for verification of the continued impermeability of the shale above the grout sheets. A sketch of these well types is given in FIg.9. All waste injections are made through slots cut in the casing and surrounding cement of the injection well. As the grout sheet spreads out from the injection well it intersects the cemented casing of one or more observation wells. A gamma sensitive probe in the observation well will then detect the presence of the grout sheet, thereby establishing the depth of the grout sheet at that point. A network of six to eight observation wells is needed to verify the horizontal orientation of the grout sheet, The lower section of most of the observation wells is cemented with a low strength grout so that the well casing will not be pulled apart by the stresses generated by the grout sheet lifting the overburden. Instead, the low strength.grout will yield and permit the casing to rise with the overburden and relieve the stress: The rock cover monitoring wells are used to periodically determine the permeability of the shale cover rock at a depth of $600 \mathrm{ft}$. This is done to verify that accumulated stresses generated by repeated injections have not fractured the shale zone above the disposal zone and thereby endangered the isolation of the disposal zone: The existing shale fracturing facility has been used to inject 1.8 million gal of waste grout containing $550,000 \mathrm{Ci}$ of radionuclides and has performed quite satisfactorily。 This facility was originally built for a series of experimental injections of grouts containing relatively low concentrations of radionuclides. Improvements to the shielding and containment 
ORNL DWG 73-3976

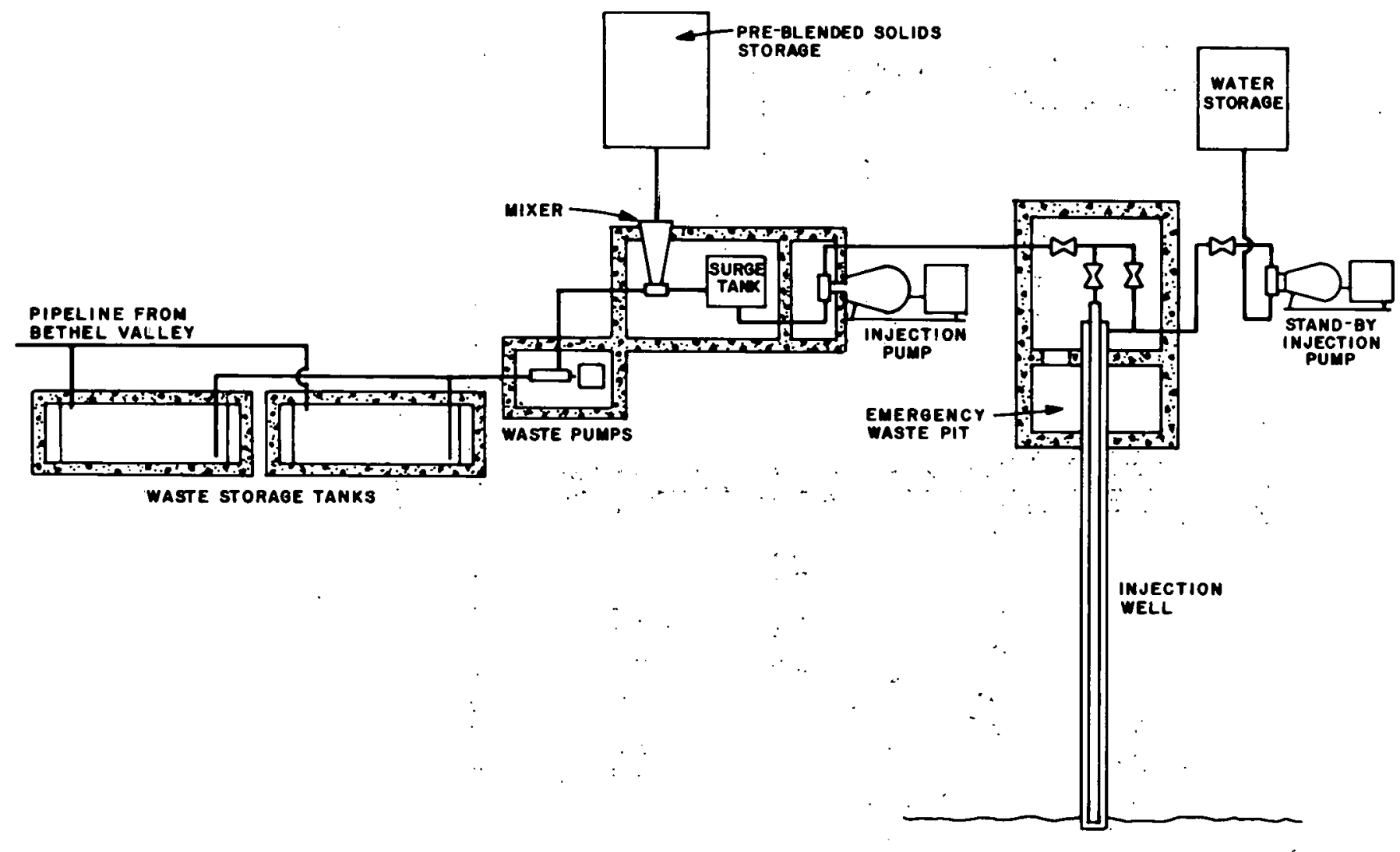

FLOW DIAGRAM OF NEW SHALE FRACTURING FACILITY

Figure 8 


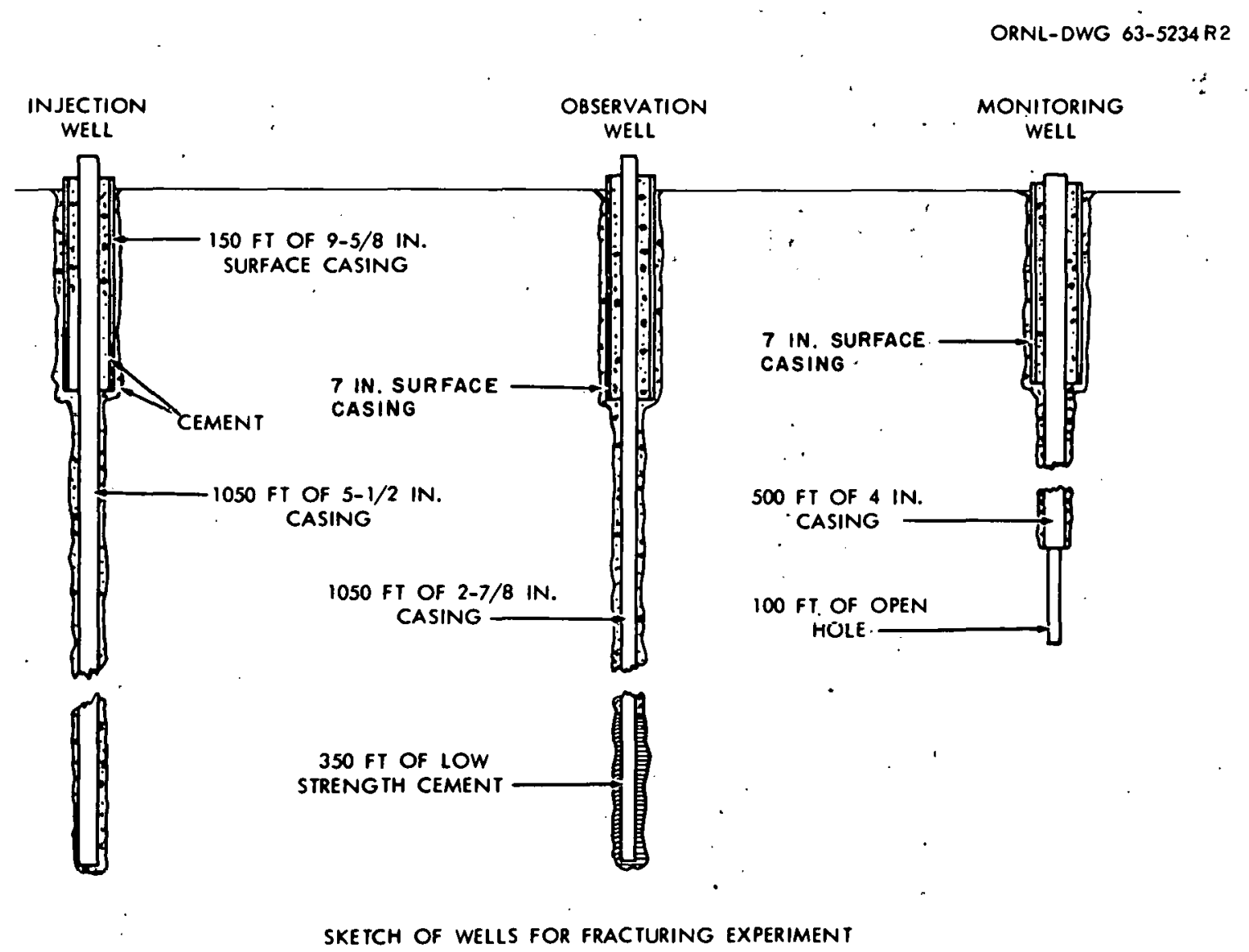

Figure 9 
have been made so that wastes with higher specific activities could be injected, but extensive additional modifications:would be required before sludges or waste solutions with specific activities higher than 1.Ci/gal could be injected. Also, much of the available shale layer underlying the present site has been ut1lized, partly by. the waste disposal injections made to date, but more particularly by the earlier experimental injections which were made to establish the feasibility of the process. For these reasons a new faclilty at.a new site: is" needed for the disposal of future wastes. This new facility would have better shielding and would inject the waste grout into an unused shale layer, but in other respects the new facility would be quite similar to the existing facility.

The existing shale fracturing facility is designed to inject about 100,000 gal of grout per injection.:-Because of this large injection volume the facility is operated in a very batchwise manner; one injection a year suffices to dispose of the Laboratory's accumulation of intermediate level waste solution. There are two reasons for this particular mode of operation. The primary reason is to maximize the useful life of the injection. well, which is strongly dependent on the number of injections that are made: and relatively independent: of the individual.injection volume. By increasing the volume of each injection (and thereby reducing the total number required to inject a volume of grout) the life of the well network is prolonged. A second incentive for making large injections is to minimize the operating cost, since a significant fraction of the operating cost is independent of the injection volume." Factors that limit. the individual injection volume include limited waste storage tank capacity; limited solids storage capacity, and operator fatigue; For the existing disposal facility a grout injection volume of $100,000 \mathrm{gal}$ has been found to be an acceptable compromise. 0il well cementing pumps were available with injection rates of up to $250 \mathrm{gal} /$ min; at this injection rate the total injection time would be about eight hours. These design parameters have been adopted with little change for the new injection facility. The design solids storage capacity has been increased by about $20 \%$, but the injection rate remains the same. The design details of the new facility are given in Ref。9.

The vulume of concentrated waste solution that is generated at ORNL each year $(80,000 \mathrm{gal})$ can be disposed of by one injection. The disposal 
of the accumulation of ILW sludge would require many injections, however. The exact number of such injections that would be required is somewhat speculative at this time. This number would be an inverse function of the maximum solids concentration in a pumpable slurry and would also depend on the leachability of radionuclides from grouts made from slurries with different solids contents. These data are not presently available: In the absence of this experimental information it is postulated in this study that slurry that is $13 \%$ by wt solids will be pumpable; can be mixed with cement in equipment that is essentially identical to equipment used for mixing ILW solution, and that the grout that is formed will have acceptably low leach rates for all.significant:radionuclides. If a slurry of this concentration is mixed with grout and injected, a total of thirty injections would be required to dispose of $\mathrm{ORNL}^{\prime} \cdot \mathrm{s}$ sludge inventory. Since the concentrated ILW solution could be used for part of the diluent required to dilute the sludge to a $13 \%$ concentration, the total number of injections required would not be additive.' Three yearly sludge injections would suffice to dispose of the solution and sludge generated in that year and a tenth of the accumulated sludge inventory.: Alternatively, more frequent injections could be made to dispose of the accumulated sludge in a shorter time.

\subsection{Operational Procedure}

Prior to an injection at the existing facility the waste solution is pumped to the waste storage tanks at the injection site. The cement, fly ash, and other dry solids are blended and stored in storage bins at the injection facility. Samples of waste solution are analyzed and nonradioactive synthetic waste is prepared. This waste is tested with samples of blended solids taken from the storage bins to verify the mutual compatibility of the waste and solids and to determine the best solids to liquid mix ratio to be used in the upcoming injection.

Every fourth injection, the slot in the casing of the injection well through which the: previous injections were made is plugged with a small volume of cement and a new slot is cut in the casing at a depth $10 \mathrm{ft}$ higher in the well。 This is done by pumping a slurry of sand and water down the central tubing string in the injection well and out a jet at the bottom of 
this tubing string to impinge upon and erode the casing, cement, and surrounding shale at that point. The jet-is rotated during this operation so that a complete $360^{\circ}$ cut is made. The jet is then pumped out of the tubing string and the well is pressurized until the formation fractures (signaled by a sudden decrease in' wellhead pressure)。

During an injection waste solution is pumped to the mixer, continuously mixed with the preblended solids and discharged into the surge tank. From the surge tank the grout is pumped. down the tubing string in the injection well and out into the shale formation. The solids to liquid mix ratio and the solution and grout flow rates are controlled to insure the grout has the desired properties. This control of the mix ratio is achieved by determining the waste flow rate with a fluid flowmeter, determining the solids flow rate with a "mass flowmeter". (a device that continuously weighs the flow of solids through it) and integrating these signals to provide a continuous readout of the mix ratio。 An operator continuously adjusts the flow of solids to the mixer to maintain this ratio at the desired value. A second operator adjusts the speed of the injection pump to maintain a near constant grout level in the surge tank. This system works well when the flow of solids is uniform, but is more.difficult to control when the solids flow is irregular, as, for instance, when a solids bin runs empty. Fig. 10 shows the measured mix ratio during a recent injection and illustrates the normal variation in this parameter.

The normal flow rate of waste solution is about $180 \mathrm{gal} / \mathrm{min}$, the normal mix rat1o $1 \mathrm{~s}$ about $7.5 \mathrm{lbs}$ of snlids per gallon of waste, and the normal; grout injectlon rate is about $250 \mathrm{gal} / \mathrm{min}$. An injection requires about $8 \mathrm{hrs}$ to complete. At the end of the injection the well is flushed with water. A small excess of water (about 100 gal) is used so that the slot in the injection well will be free of grout and can be reused for the next injection. The facilfty is washed and the well is shut in under pressure to permit the grout to set.

\subsection{Injection Monitoring}

During the injection the wellhead pressure is monitored for any sudden: unexplained drop, which might be an indication of the formation of a vertical fracture. Vertical fractures are common in the petroleum industry; 
ORNL OWG 73-12718

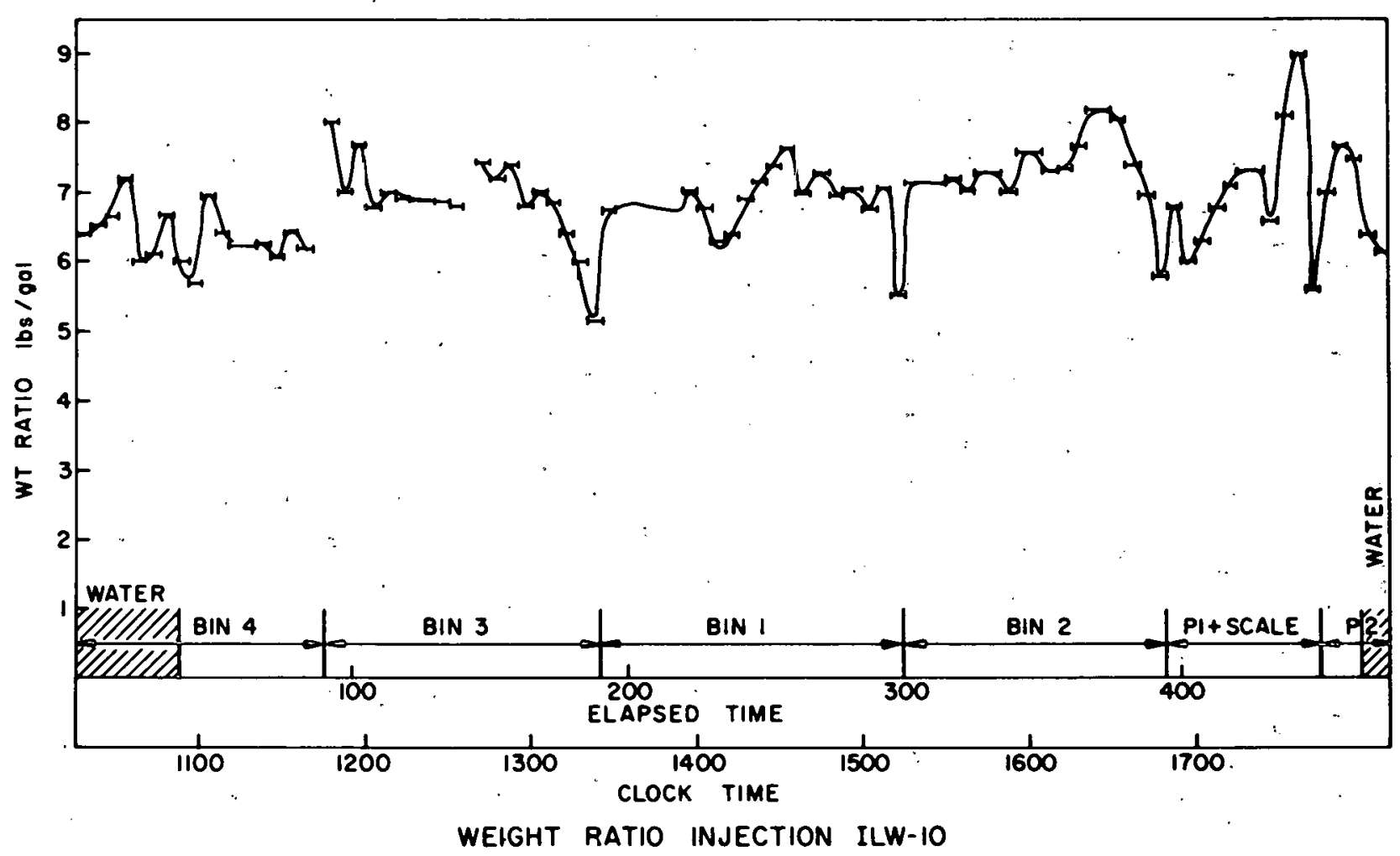

Figure 10 
they are fractures with one axis in a vertical or near vertical plane: They are of concern in this application because of the possibility that such a fracture could provide a pathway for radionuclide migration to the groundwater. No such fracture has been observed in the bedded shales at Oak Ridge and the likelthood of such a fracture being formed is regarded as very smal1. This point is:discussed further in Section 7.6 。

After the injection the observation wells are monitored to determine the orientation of the fracture. At intervals of two years or flve injections; the rock cover wells are checked to verify the continued impermeability of the overburden. The surface uplift generated by the injections is periodically determined by surveys of a benchmark network. Each injection typically generates a small surface uplift. This uplift is typically about $0.15 \mathrm{in}$. near the injection well and decreases to near zero at 1200 to $1500 \mathrm{ft}$ from the well. Fig, 11 is a plot of measured uplift near the existing disposal site. The slgnificance of these uplift measurements is not certain.

Several weeks after the injection. is concluded, routine bleed-back of any free water that might be present in the disposal formation is carried out. This bleed-back water is collected and fed back to the intermediate level waste system. This operation removes from the disposal formation any free water that might be present because of grout mix vartability and leaves the radionuclides fixed in the grout. The specific activity of the bleed-back solution is much lower than the specific activity of the original waste solution. The specific activity of ${ }^{137} \mathrm{Cs}$ in the bleed-back water, for instance, is about $1 \%$ of its specific activity in the waste.

\subsection{Operational History}

The existing disposal facility was built in 1962 and a series of experimental waste injections was made in 1964 and 1965 to demonstrate the feasibility of the process. In 1966, the facility was modified for the routine disposal of waste solution; it has since been used for the injection of $1,303,000 \mathrm{gal}$ of waste solution containing $520,000 \mathrm{Ci}$ of ${ }^{137} \mathrm{Cs}$ and $36,800 \mathrm{Cl}$ of ${ }^{90} \mathrm{Sr}$. Some of the parameters of these injections are listed in Table 9 . 


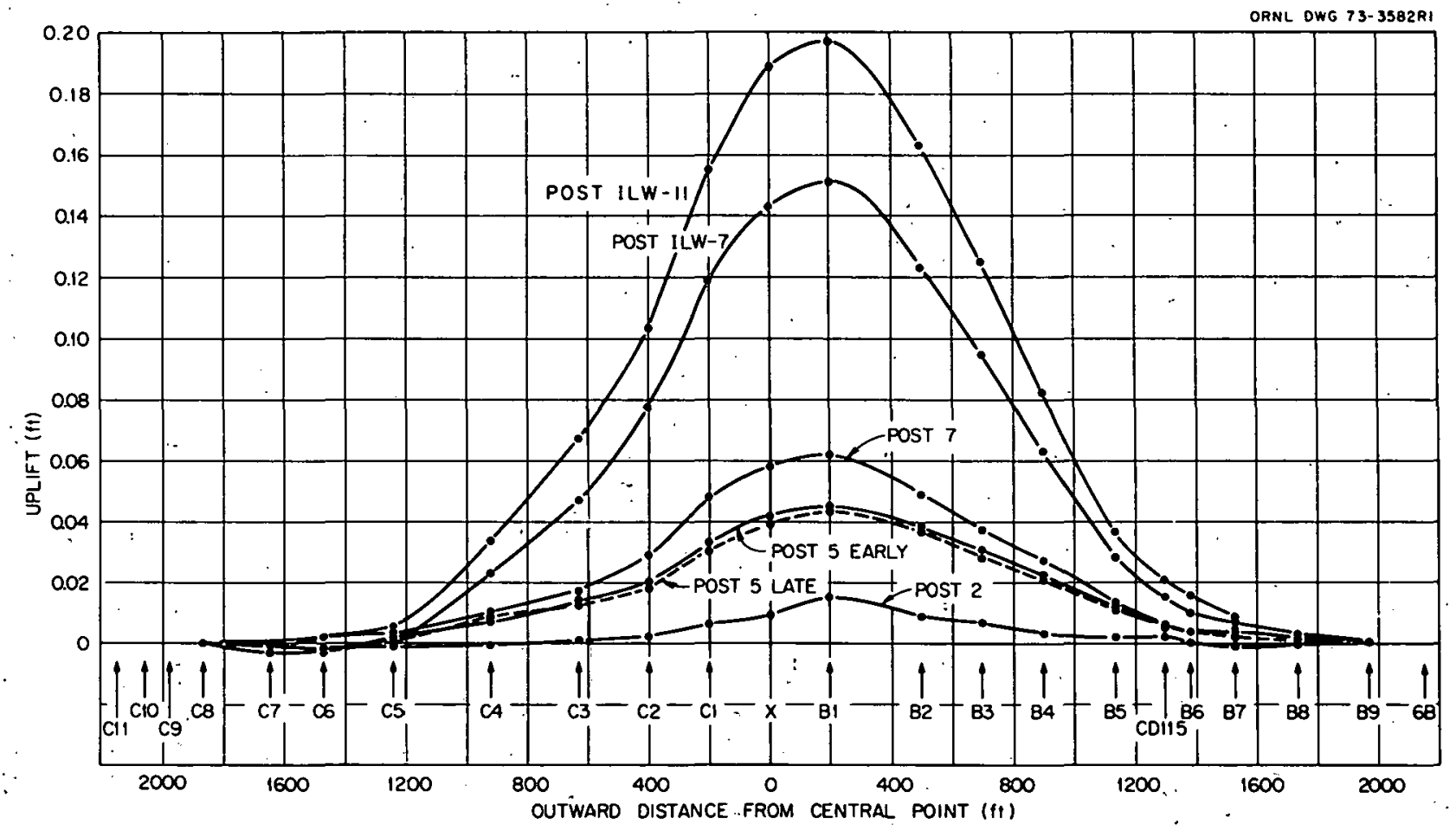

Figure 11 
Table 9。 Injection Parameters for Routine Disposal of Waste Solution

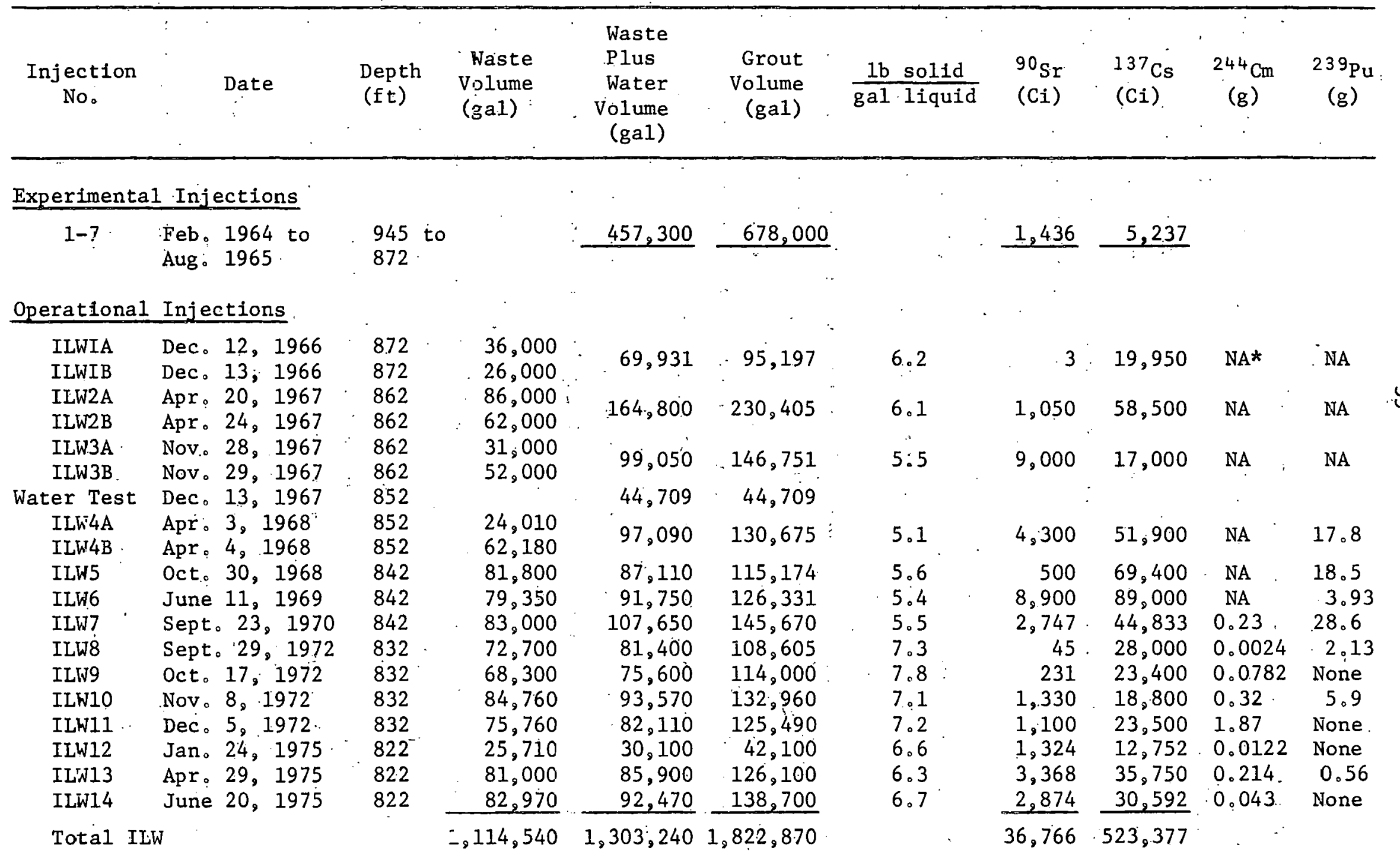

$\mathrm{NA}=$ not analyzed 
The operation of the shale fracturing facility during this series of injections has not been.without problems, but most of these problems have been comparatively minor. - With the exception of two injections (discussed below) the difficulties have not been serious enough to force the termination or major delay of an injection. They have required at most a relatively short shutdown of the injection while repairs were made. These difficulties include such miscellaneous.items as eroded check valves.in the injection pump, a plugged drain line from the injection pump sump, a ruptured solids supply line connection, loss of prime on the waste pump, jamming of the clutch on the injection pump, bridging of solids in the feed hopper and a leak past the sealing ring of one of the high pressure valves. Each incident has been an isolated occurrence; none has caused serious difficulty。

One injection that had to be ended prematurely because of operational difficulties was Injection ILW-12; This injection was scheduled for October 1974, and preliminary preparations had almost been completed when the injection date was delayed. At this time all of the solids to be used in the Injection had been blended and stored. Preparations for the injection were resumed after a three month interval and the suitability of the stored solids was questioned. Some nonconclusive tests were made that indicated that some deterioration in flowabillty had occurred but that there was no certain indication that the solids were unusable. In the absence of any real operating data on long stored solids, the decision was reached to attempt the injection with the old solids. The injection went very poorly; the solids would not flow out of one storage bin at all and flowed very erratically out of the others. This difficulty with solids flow caused great difficulty with mix control and resulted in very.irregular operation of the injection pump. This was probably a major cause of a series of minor malfunctions (such as those listed above) that resulted. A total of $25,700 \mathrm{gal}$ of waste and $4400 \mathrm{gal}$ of water was injected before the futility of continuing the injection under such conditions was acknowledged and the injection was ended. This somewhat abortive injection points up the importance to the process of having solids that flow easily without clumping, sticking, and bridging。 
Injection ILW-14 was abruptly halted when the packing on one piston of the injection pumped failed, resulting in the discharge of some waste grout into the pump cell. The stand-by injection pump was used to clear grout from the well and high pressure piping. The spilled grout was cleaned up and the injection pump was repaired. The injection was resumed after a two-day delay and was: completed without further difficulty.

General experience with the shale fracturing facility in fourteen operating injections has been quite good.... Large volumes of waste solution have been continuously mixed with dry solids in the desired proportions and injected into the isolated shale beds. The clean up of small waste spills has been found to be feasible, as has the direct maintenance of mechanical equipment. . Observed process shortcomings include the improper location of some equipment (with consequent difficulty of maintenance), some difficulty in obtaining a steady solids flow under all conditions, and a marginally effective control of solids to liquid proportioning. These shortcomings are not serious and could be alleviated or corrected in a new facility.

\subsection{Operationai Requirements}

The major operating costs for the injection of a batch of waste are the costs. for the $\mathrm{mix}$, the service charges of an oil well cementing company (Halliburton) for making the injection and the cost of ORNL labor and services for preliminary preparations and assistance during the injection. These costs vary from one injection to the next, and since no injection is entirely typical, no set of costs for a single injection is quite complete; an average for several injections is probably more meaningful.

The injection serles ILW 8, 9, 10, and 11 was made between September and December of 1972: In this series of injections, 301,500 gal of waste and 31,200 gal of water were mixed with solids and injected. The overall. costs for this series are given in Table 10 .

The extraordinary items listed in Table 10 are the cost for replacement of much of the high pressure piping in the system, which was done at the start of this particular injection series. The costs of these items are not typical and should be amortized over more than four injections to obtaln a more meaningful cost per injection or cost per gallon. 
Table 10. Costs for 1972 Injection Series ${ }^{10}$

\begin{tabular}{lr} 
Mix cost & $\$ 22,000$ \\
Halliburton services & 27,720 \\
ORNL services & 32,800 \\
Extraordinary items & 14,500 \\
Tqtal & $\$ 97,020$ \\
\hline
\end{tabular}

\subsection{Research and Development Requirements}

Disposal of ILW solution by, shale fracturing is a proven process and would require little or no additional research and development. Disposal of ILW-sludge is unproven, however, and would require some work to verify the sultability of the process for that application and to determine accept-. able values for various operating parameters.

Some mix: development work would be required to adapt the current solids $\mathrm{mix}$ : to the somewhat different requirements of sludge fixation. Much of this. work would have to be done, with samples of actual sludge, since the relevance of work done, with synthetic sludge would be questionable. An estimated four man-years of effort would be needed.

Some work on mixer operation would be needed. The smooth.functioning of this piece of equipment is essential to the process and some development work would be needed to determine how this operation could best be done with a slurry feed. Two man-years is esțimated.

\subsection{ESTIMATE OF COSTS \\ 6.1 Capital Costs}

Total project costs for a new shale fracturing facility including contingencies, are estimated at $\$ 2.6$ million (1975 dollars). These cost est1mates are summarized in Table 11 and are based on the faciltty design described in. Refo. 9 : 
Table 11. Estimated Capital. Cóst of Shale Fracturing Facility

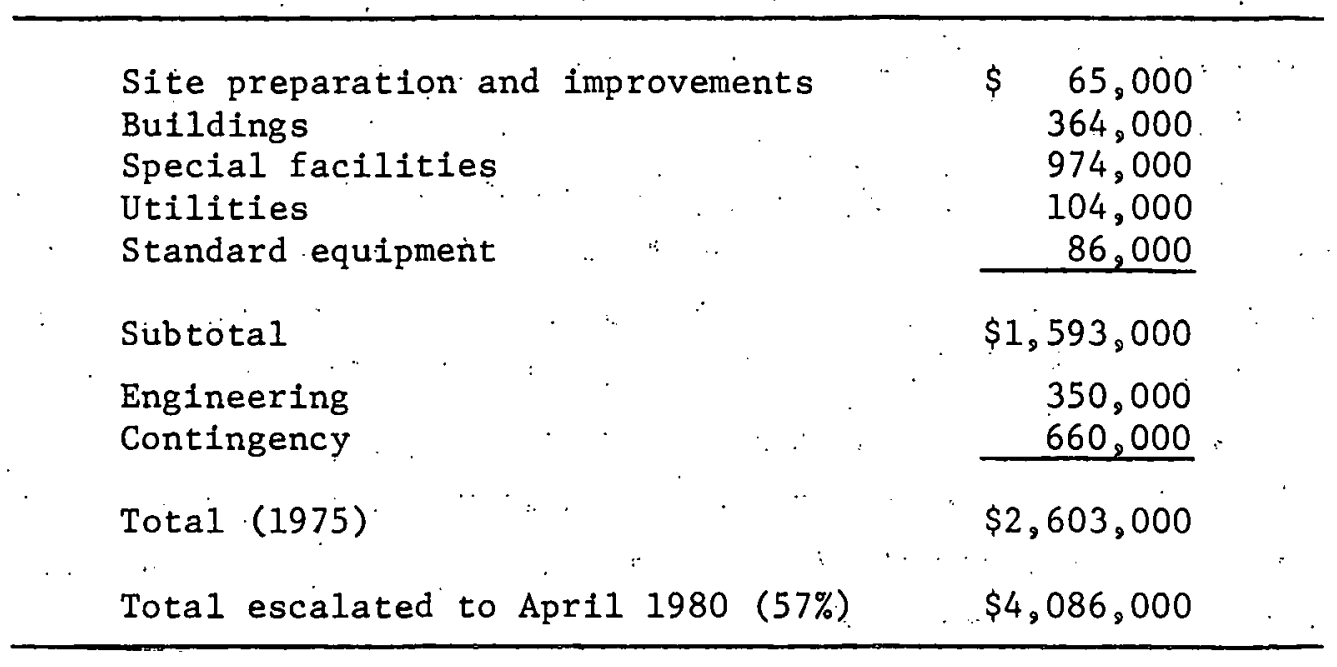

\subsection{Operating Costs}

The annual direct operating cost for the shale fracturing facility is estimated to be $\$ 93,000$. This estimate is based on the cost experience of previous injections (Section 5.5), an injection schedule of three injections per year, and a cost escalation of the 1972 costs of $10 \%$ per year for three years. During the period when accumulated sludges in the Gunite tanks are being disposed of, there may be as many as twelve injections per year with a corresponding increase in operating cost for those years operating costs in succeeding years would be lower.

\subsection{ENVIRONMENTAL AND SAFETY ASSESSMENT}

\subsection{Seismic}

Oak. Ridge is located in an area of moderate earthquake damage (Zone 2): It is about midway between the zone 3 areas of major damage centered around Charlestiul, 3uuth Carolina; and around Memphis, Tennessee, Data on earthquakes prior to 1900 are extremely fragmentary; there is only one reported shock with an epicenter within 100 miles of Oak Ridge and an intensity greater than V (modified Mercalli scale) for this periodo ${ }^{11}$ Since 1900 thcre were fifteen repnrted shocks with an epicenter within 100 miles of Oak Ridge and an intensity of $V$. There were three shocks of intensity V-VI, 
seven shocks of intensity VI. (a few instances. of fallen plaster or damaged chimneys), three shocks of intensity. VI-VIII, one shock of intensity VI-I (damage negligible in buildings of good design and construction), and no shocks of intensity greater than.VII... The one shock with an, intensity of VII occurred on March.29, 19.13; and had an epicenter at or near Knoxville, Tennessee. The nearest recorded earthquake with an epicenter greater than. VII occurred in January 1905, and had an epicenter near Gadsden, Alabama 170 miles away。: This shock was of intensity. VIII (damage slight in specially designed:structures, considerable in ordinary buildings). .

All surface structures at the new shale fracturing facility will be designed in accordance with Zone 2 seismic requirements of the 1973 Edition. of the Uniform Buflding Code.

\subsection{Winds and Tornadoes}

All surface structures at the new shale fracturing facility shall be designed in accordance with the requirements of ANSI Standard A-58.1-1972 except as noted below.

All concrete shielded cell structures shall be designed to withstand the design basis tornado now being established for the Oak Ridge area. All characteristics of this tornado will be defined by UCC-ND prior to the start of Title I design:

\subsection{Floods}

The design elevations of the floor of the waste pit of the new shale fracturing facility is $768 \mathrm{ft}$. The maximum probable flood that has been estimated for the Clinch River watershed is $768 \mathrm{ft}$ at the discharge of White Oak Creek。12 A flood of this magnitude, would not be expected to have any effect on the fracturing facility; all structures of the facility will be well above'this flood stage. If the flood crest were higher than that of the maximum probable flood, no effects would be anticipated until the crest reached $779 \mathrm{ft}$; at this crest level the waste pit could be flooded and some activity could start migrating into the emergency waste pito Any activity that migrated from the waste pit would be retained in the emergency waste pit until the flood level reached an elevation of $786 \mathrm{ft}$ 。 


\section{$7.4:$ Fallure of Services}

A fallure of services that occurs at any time except during an injection will have no effect on any part of the disposal facility. A failure of services during an infection will force the termination of the injection, unless the failure is of short duration (no more than fifteen minutes). The facility is designed-so that elther the Injection pump or the standby injection pump can be used to clear the injection well and end an injection in case of need. These pumps are diesel-powered and would not be affected by a service failure.

\subsection{Fire}

The facility will be protected by means of a wet pipe sprinkler system In: al1 areas except those for the two diesel-powered injection pump drives where, deluge protection will be provided. These two areas will also be . separated by means of a four-hour rated wall and a separate underground fuel tank will be provided for each drive.

\subsection{Leaks and Accidents}

Waste solution will be stored in the new waste storage tanks in Melton Valley。 These tanks and their integrity have been described in Ref.2。 During a shale fracturing injection, waste solution will be pumped from these storage tanks to a mixer where the waste will be mixed with cement solids to form a grout. The waste-cement grout will be pumped down the injection well and out into the shale formation at a depth of 800 to 1100 ft. The underground transfer lines that carry the waste solution into the cell structure w1ll be doubly contained and monitored to detect any leakage that might occur. The cell structure will be designed to provide secondary contalnment for ail waste and grout handling piping, and equipment installed within the cells. These cells and the mixing tub will be equipped with ventilation and off-gas systems designed to prevent the release of airborne contamination。

The likelihood is remote, but it is possible for a wellhead rupture to occur late in the course of an injection and allow a large volume of grout 
to flow back out of the disposal formation and up the injection well. The consequences of such an accident have been minimized by the inclusion of enclosed emergency waste pit in the lower part of the main cell structure for the purpose of collecting and containing the maximum expected flowback. No release of radionuclides would pe expected in this case.

A small volume of water normally separates from the grout as it sets. This water will contain some radionuclides and will be allowed to bleed back up the injection well-for collection and return to the waste storage tanks. Wash water and the other residues from the well casing slotting operation will be collected in the waste pit for injection with the next batch of waste solution or transfer back to the storage tanks.

It is possible for the orientation of the fracture formed in the shale during a waste injection to be vertical rather than horizontal, and thus allow some quantity of grout to reach the surface of formations near the surface that contain circulating water. The formation of such a vertical fracture in the bedded shales at oak Ridge during a waste injection is considered to be highly improbable. Nearly thirty fractures have been made in the bedded shale at Oak Ridge, and all of these fractures have been essentially horizontal. Even if a vertical fracture should be formed, however, the depth of the injection zone is so great that only a fracture with a very unusual geometry (very long and very narrow) could approach the surface. The consequences of such an incident have been evaluated, however, and found to.be small. The leach rates of significant radionuclides from any ejected grout would be low and the net loss of radionuclides would be small, even under the worse conditions. For most of the accident situations postulated, the radionuclide concentration in the Clinch River would not exceed the concentration guide. ${ }^{13}$ For the worst postulated situation, the estimated life-time dose to the critical organ of a person drinking water from the Clinch River would be between 70 and 100 millirems. Drilling operations in the vicinity of the disposal formation are not likely to be of concern. Wells have been drilled through grout sheets at the existing site and only minor amounts of activity have been found in the drilling water. 


\section{$7 \cdot 7$ Long. Term Safety}

The permanence of disposal of radioactive wastes by the shale fracturing process is exceptional: The disposal formation is quite impermeable and no mechanism is known that would result in surface water reaching the grout sheets. Even i.f water should reach the grout sheets by some mechanism, the quantity of radionuclides leached would be exceedingly low. The impermeablilty of the shale above the disposal formation is periodically monitored by means of rock cover wells to detect any change in shale permeability that might occur.

\subsection{Analysis of Environmental Impact}

The overall environmental impact of the new shale fracturing facility is expected to be beneficial. The facility will remove large volumes of potentially hazardous radioactive wastes from the existing surface storage facilities and fix these wastes in impermeable shale formations, well removed from the blosphere. The possible adverse environmental effects from normal, operation (a minor rise in the temperature of the shale formation caused by heat generation of embedded wastes and a very small ground surface uplift) are not considered to be significant. All major accident situations postulated are considered to be quite improbable and the analysis of each case has indicated the ultimate release of radionuclides to the environment to be small.

\subsection{COMPARISON · WITH ALTERNATIVE PROCESSES}

A study has been made of possible alternative processes that could be used for the safe-storage or disposal of the ILW solution and ILW sludge that are generated or stored at ORNL. ${ }^{1}$ Three possible alternative processes. were selected for detailed study and estimates of capital and operating costc. The shale-cement process fixes the waste in a cement matrix and stores the waste in drums in a storage vault: The cesium strip process removes the radionuclides from the waste solution by ion exchange; the decontaminated waste solution is mixed with cement and pumped into a trench or disposed of by shale fracture. In the glass fixation process the waste. 
is converted to a glass at $950^{\circ} \mathrm{C}$ and the glass is stored in a storage vault. In each of the three alternative processes the waste radionuclides are fixed in a solid, noncombustible form with low leachability. In each of the three processes the final. waste form is stored in a facility from which it can be. retrieved。

The shale fracturing process is a method for the fixation and permanent disposal of ORNL waste solution and sludge into a geologically isolated zone. It is a process that has been operational for almost ten years and that has attractively low capital and operational costs. The alternative processes are conceptual schemes for the fixation and storage of waste solution and sludge. The ultimate disposal of the immobilized waste is not a part of these processes.

A comparison of the estimated capital costs, the research and development costs, and the annual operating costs for the various processes is shown in Table 1 。 


$$
111
$$




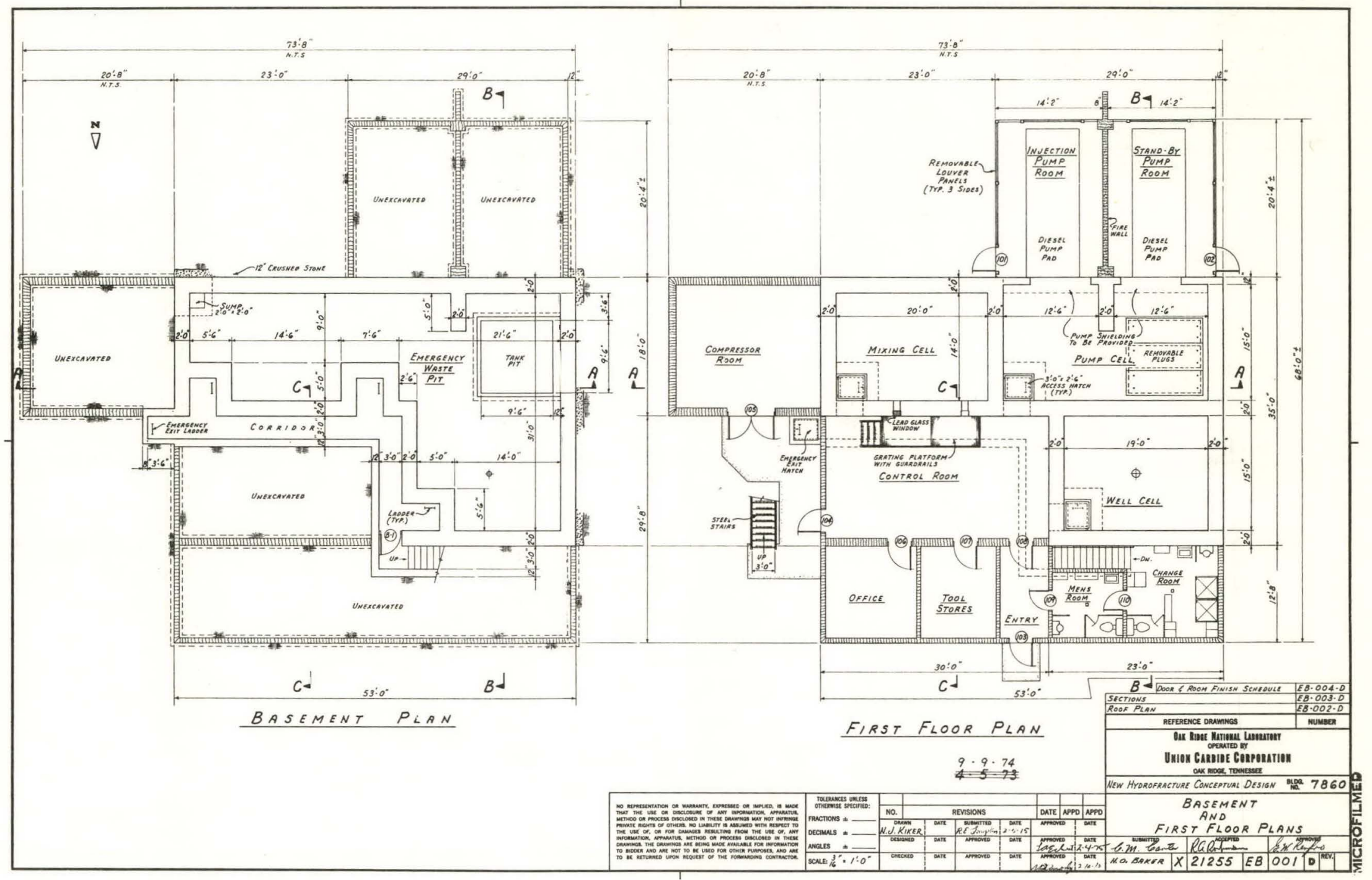




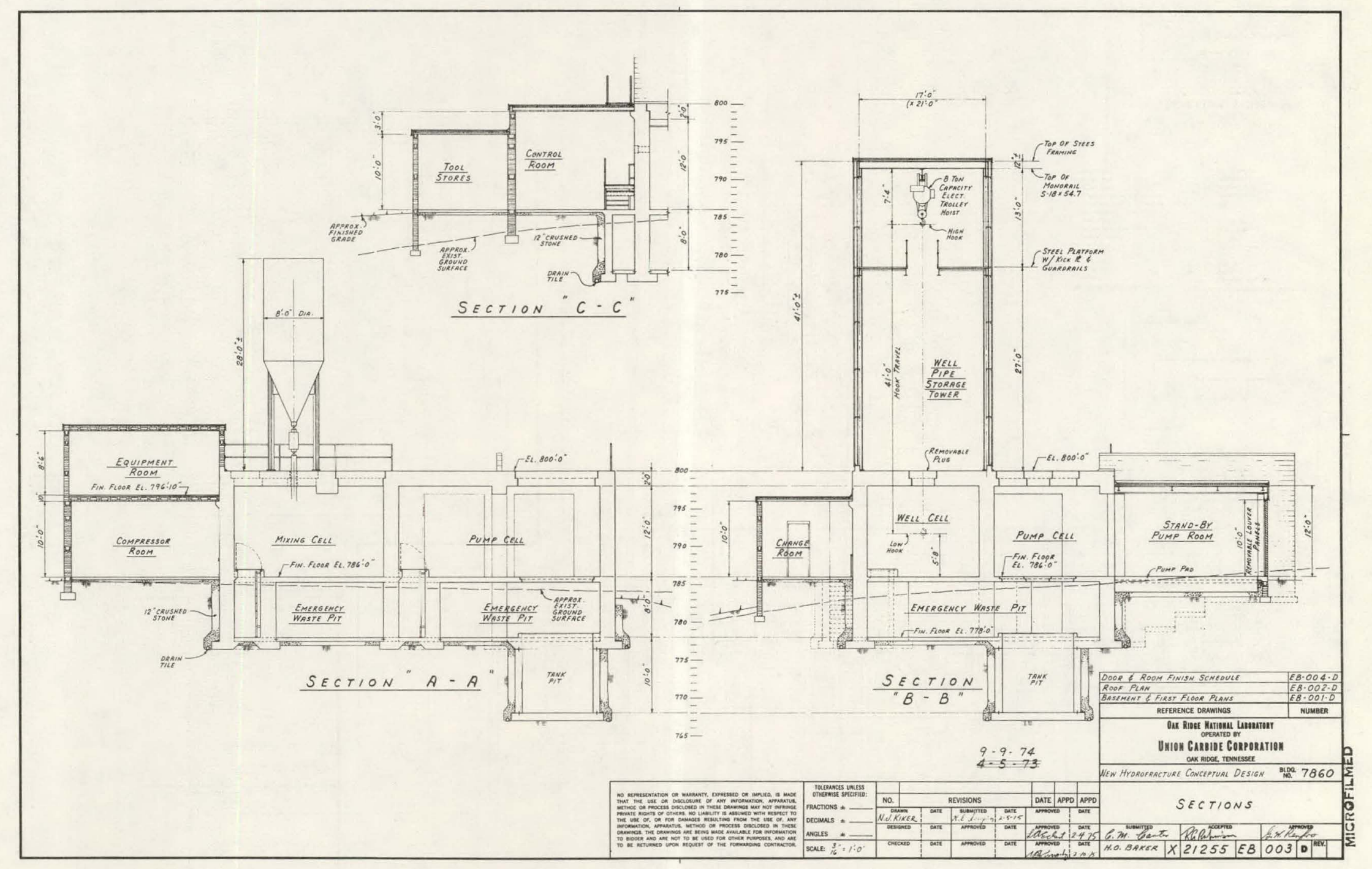




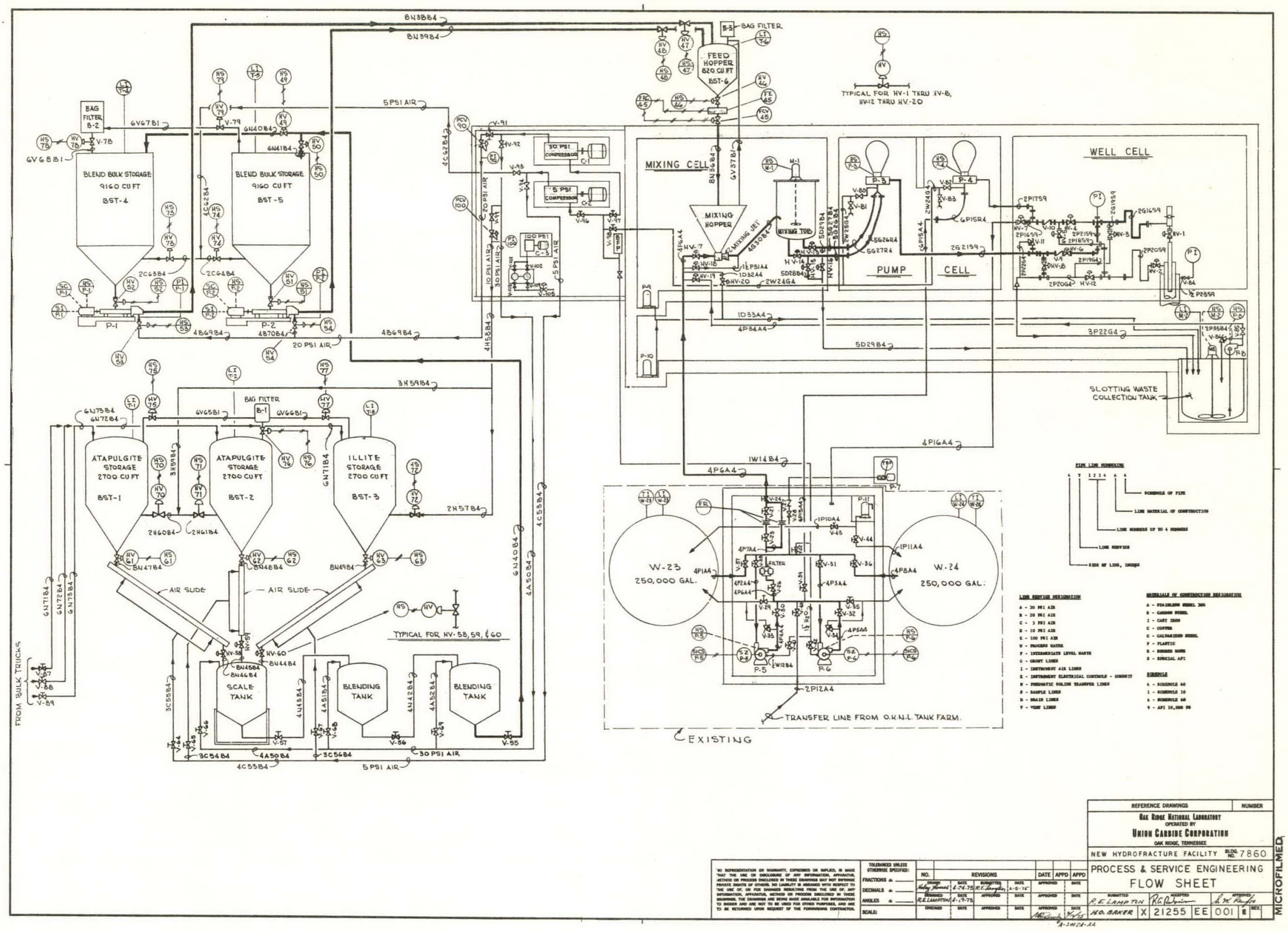




\section{REFERENCES}

1. Ho . Weeren, F. T. Binford, J。 O. Blomeke, Study of Alternative Methods for the Management of Waste Solution and Sludge at Oak Ridge National Laboratory, ORNL-TM-5208 (in preparation):

2. Environmental Statement - Radioactive Waste Facilities at ORNL; Oak. Ridge, Tenn。, WASH-1532 (Aug。1974)。

3. H. O. Weeren, Shale Fracturing Injections at ORNL - 1972 Series, ORNLTM-4467 (June 1974)。

4. Jo Go Moore, Ho Wo Godbee, A。 H。 Kibbey, O。 S。 Joy, Development of Cementitious Grouts for the Incorporation of Radioactive Wastes, ORNL-4962 (Apr。1975)。

5. J. G. Moore, Oak Ridge National Laboratory, Personal Communication, Oct. 18, 1974 .

6. Wo de Laguna, H。 O. Weeren, F。T. Binford, E。 J。 Witkowski, E。 G : Struxness, Safety Analysis of. Waste Disposal by Hydraulic Fracturing at Oak Ridge, ORNL-4665 (Sept.1971).

7. Wo de Laguna, et a1., Engineering Development and Hydraulic Fracturing as a Method for Permanent Disposal of Radioactive Wastes, ORNL-4259 (Aug: 1968)。

8. Ho O. Weeren, G。 D。 Brunton, Wo de Laguna, J.G. Moore, Hydrofracture Site Proof Study at Oak Ridge National Laboratory, ORNL-TM-4713 (Nov。 1974).

9. R. E。 Lampton, R.A. Robinson, H. O.Weeren, Conceptual Design Report, New Hydrofracture Facility, ORNL-TM-4826 (July 1975)。

10. L. C. Lasher, Oak Ridge National Laboratory, Personal Communication, March 6, 1975 .

11. W。 Co Mcclain and O. Ho Myers, Selsmic History and Seismicity of the Southeastern Region of the United States, ORNL-4582 (June 1970)。

12. Floods on Clinch River and East Fork Poplar Creek in Vicinity of Oak R1dge, Tennessee, TVA Report No, 0-5922 (Septo 1959).

13. "Standards for Radiation Protection," AEC Manual, Chap: 0524, Annex A (Nov, 1968). 
THIS PAGE

\section{WAS INTENTIONALLY LEFT BLANK}


INTERNAL DISTRIBQUTION

1. R。 Go. Affel

2. F: T. Binford

3. J。 0. Blomeke

4. R。 E。 Brooksbank

5. Ko B. Brown

6. F。 R. Bruce

7. $\therefore$ G。 D。 Brunton

8. J. A: Cox

9. F. L. Culler

10: G。 J. Dixon

11。.. D。 E: Ferguson

12. H. W. Godbee

13. A. T : Gresky

14. R. Mo Hill

15. B. L. Houser

16... L。 C. Lasher

17. A. P. Malinauskas

18. W. C. McClain

19: J: Go Moore

20: Ho Postma

21. M. E。 Ramsey

22. Ro Ao Robinson

23. Co D。 Scott

24. P. E. Stein

25. E. G. Struxness

$26 \%$ T. Tamura

$2,7-36 \%$ H. O. Weeren

37. E. Jo Witkowski

38.. R。 G. Wymer

39-40. Centrai Research Library

41. Document Reference Section

42-44. Laboratory Records Department

45. Laboratory Records - ORNL R.C.

46. ORNL Patent Office 


\section{EXTERNAL :DISTRIBUTION}

47. F。 P. Baronowski, ERDA-Washington

48. Wo P. Bishop, Nuclear Regulatory Commission, Bethesda, Maryland

49. R。 L。 Chandler, Savannah River "Operations Office, Aiken, S。C., 29810

50. C. R。 Cooley, Hanford Engineering Development Laboratory, Richland, Washington, 99352

51: Ko E。 Cowser, ERDA-Washington

52。G。H。Daly, ERDA-Washington

53. Wo Ko Davis, Bechtel Power Corporation, San Francisco, California, 94119

54. J.C. Frye, Geological Society-of America, 3300 Penrose Place, Boulder, Colorado, 80301

55. 0. P. Gormley, ERDA-Washington

56. R. B。 Goranson, Richland Operations Office, Richland, Washington, 99352

57. Wo Ho Hale, Savannah River Laboratory, Aiken, S。 Co, 29810

58-61。 E。 Ho Hardison, ERDA-ORO

62. H. Lo Hull, Savannah River Laboratory, Aiken, S。C., 29810

63. C。Ho Ice, Savannah River Laboratory, Aiken, S, Co, 29810.

64: A. S。 Jennings, Savannah River Laboratory, Aiken, S. C., 29810

65. L。 Jo Johnson, Los Alamos Scientific Laboratory, Los Aiamos, N. Mo, 87545

66。-J。 J。 Katz, Argonne National Laboratory, Argonne, Illinois, 60439

67. - T。Ko Keenan, Los Alamos Scientific, Los Alamos, N。 Mo, 87545

68. Ko Ko Kennedy, Idaho Operations Office, Idaho Falis, Idaho, 83401

69. M. R。 Kreiter, Battelle Pacific Northwest Laboratory, Richland, Washington, 99352

70. A. M. Platt, Battelle, Pacific. Northwest Laboratory, Richland, Washington, 99352

71. R。 Wo Ramsey, ERDA-Washing ton

72. R: B。 Richards, General Electric Company, 175 Cùrtner Ave., San Jose, California, 95100

73. J。 J。 Schreiber, ERDA-ORO

74. Wo Wo Schluz, Atlantic Richfield Hanford Company, Richland, Washington, 99352

75. C. M: Slansky, Idaho Chem Plant, Idaho Falls, Idaho, 83401

76. Mo Steinberg, Brookhaven National Laboratory, Upton, N. Y., 11973

77. R。 Do Walton, ,ERDA-Washington

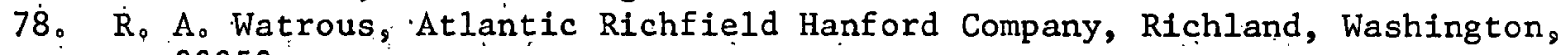
99352

79. D。D。Wodrich, Atlantic Richfield Hanford Company, Richland, Washington, 99352

80。 Research and Technical Support Division, ORO

81-107. Technical Information Center, OR 